\title{
Different types of sediment gravity flows detected in the Var submarine canyon (northwestern Mediterranean Sea)
}

\author{
A. Khripounoff ${ }^{a}, *$, P. Crassous ${ }^{a}$, N. Lo Bue ${ }^{b}$, B. Dennielou ${ }^{c}$, R. Silva Jacinto ${ }^{c}$
}

\author{
a IFREMER/Brest, Dep. REM/EEP/LEP, BP70, 29280 Plouzané, France \\ b INGV, Via di Vigna Murata, 605, 00143 Roma, Italy \\ ${ }^{\mathrm{c}}$ IFREMER/Brest, Dep. REM/GM, BP70, 29280 Plouzané, France \\ *: Corresponding author: Alexis Khripounoff, Tel.: +33 298224302 ; \\ email address : Alexis.Khripounoff@ifremer.fr
}

\begin{abstract}
:
Current velocities and vertical sediment fluxes in the Var submarine canyon were assessed at three stations respectively at $800 \mathrm{~m}, 1200 \mathrm{~m}$ and $1800 \mathrm{~m}$ depth, using moorings deployed for 4 months during winter 2008-2009. During this period, we observed three major sediment gravity flows, all characterized by sudden increases in current velocity that lasted $2-5 \mathrm{~h}$ and by downward particle fluxes. Each gravity flow, described using a high frequency current meter and two Acoustic Doppler Current Profiler ( 75 and $300 \mathrm{kHz}$ ADCP) showed distinctive features. The first event, triggered during a flood of the Var River, was determined to be a hyperpycnal current with a large vertical extent $(>100 \mathrm{~m}$ high) and relatively low velocity $\left(40 \mathrm{~cm} \mathrm{~s}^{-1}\right)$. The second event, observed after a Var River flood, was more energetic with a maximum horizontal current peak of $60 \mathrm{~cm} \mathrm{~s}^{-1}$ but with a low vertical extent (30 $\mathrm{m}$ high). This event was considered to be a turbidity landslide. The third was the result of a local canyon wall failure. It was characterized by a speed of $>85 \mathrm{~cm} \mathrm{~s}^{-1}$. These peaks of current speed were associated with large clouds of material that transported sediment along the canyon and reached up to $200 \mathrm{~g} \mathrm{~m}^{-2} \mathrm{~d}^{-1}$ of sediment $\left(>1 \mathrm{~g} \mathrm{~m}^{-2} \mathrm{~d}^{-1}\right.$ of organic carbon). Our measurements in the Var canyon show the important role of gravity flows transporting particulate matter to the deep-sea floor. These large inputs of sediment and organic carbon may have a significant impact on deep-sea carbon storage in the Mediterranean Sea.
\end{abstract}

\section{Highlights}

- The floods of the Var River explain the trigger of the hyperpycnal currents in the Var submarine canyon. Three gravity flows were observed in the Var canyon characterized by increase in current and particles. - Gravity flows transported lot of material along the entire canyon. - The large input of sediment has a significant impact on the bottom of the deep Mediterranean Sea. 


\section{Introduction}

Submarine canyons have been recognized as special paths for sediment transport from the continental margins to the deep sea (Gardner, 1989; Khripounoff et al., 2003; Khripounoff et al., 2009; Liu et al., 2006; Palanques et al., 2005; Vangriesheim et al., 2009). They also probably play an important role in the global marine environment. The main sediment sources feeding into these canyons derive from direct river input or resuspension of shelf sediment deposition. The activation of these sediment sources is seasonal and episodic. However, the transport processes in these submarine canyons are still largely unknown. The term "gravity flow" covers a large range of phenomena, but all gravity flows always are the result of density differences. Gravity flows are initiated by one or more of several processes such as sediment failure induced by seismic activity or retrogressive unstable landslides at the head of canyons and at the canyon flanks (Piper et al., 1999), storm-generated flows near shelf edges, or "plunging" flows of sediment-laden freshwater (see review by Piper and Normark, 2009).

The vertical structures of suspended material concentration and velocity in the main body of the current are responsible for sustained scouring or deposition on the ocean floor. To analyze the effect of gravity currents on the input budget in the deep sea, it is first necessary to understand the dynamics of these currents. Various studies have explored the nature of gravity flows. The physical behavior of gravity flows has been investigated experimentally in a plunge region (Lee and $\mathrm{Yu}, 1997$ ). The vertical structure in the main body of the current has also been studied by Siegenthaler and Buhler (1985), Garcia and Parker (1989) and Xu et al. (2010). The flow and concentration fields at the leading head of the flow have been modeled in laboratories (see Choux et al., 2005; Felix et al., 2005). Nevertheless, despite considerable advances in our knowledge on this geophysical process, gravity flow dynamics are still not well understood.

In this paper, we present a new approach for analyzing gravity flows generated by the plunging of river flow. We studied particle fluxes and hydrodynamic responses of the Var submarine canyon to episodic river floods. By analyzing in situ data obtained with current meters and sediment traps moored along the canyon, we determined the relationships between observed gravity flows and different forcing factors, such as high river flows. However, other events appeared not necessarily linked to the river flow. Finally, we interpret the different observed sediment fluxes in the canyon with regard to possible trigger mechanisms.

\section{Regional setting}

The Var River and the Var submarine canyon are located in the French Riviera near to the city of Nice (northwest Mediterranean). The nearby continental shelf is very narrow (maximum 2 to $3 \mathrm{~km}$ ) and is virtually absent off Nice. The Var canyon cuts across it and the Var River delivers its sediment-laden water directly into the canyon head. The Var submarine canyon sensu stricto is $16 \mathrm{~km}$ long (cf. Klaucke et al. 2000; Migeon et al. 2012). The canyon is about $300 \mathrm{~m}$ wide at its head and 1000 wide at its end. It presents a mature U-shaped transverse profile. The canyon floor is covered by a giant field of gravel and boulder waves (Malinverno et al. 1988; Mulder et al. 1997; Klaucke et al. 2000) indicative of high energy currents. Further down the canyon, where gravity currents have lost some energy, the bottom of the canyon is mainly sandy (rippled sand bars cut by furrows). From 1200 to 1600 $\mathrm{m}$ depth, the sediment becomes coarser in the main axis (gravel waves) with small sandy mud terraces to the left of the flow. These features continue to the end of the canyon, where 
the Var and Paillon canyons coalesce at $1750 \mathrm{~m}$ depth. A complete description of the Var turbidity system is given in Mulder et al. (1998).

The Var River flows through a highly mountainous drainage basin of about $2830 \mathrm{~km}^{2}$ that is characterized by a pronounced meteorological seasonal regime with important flash floods in autumn (storms) and spring (snow melting) (Sage, 1976). Heavy rainfall triggers the transport of terrigenous material, which is injected directly into the head of the Var canyon. The annual mean flow of the Var River is only $50 \mathrm{~m}^{3} \mathrm{~s}^{-1}$ but floods at its mouth may reach flow rates of up to 10 times greater than the mean flow in just a few hours. Floods in the Var can reach more than $1000 \mathrm{~m}^{3} \mathrm{~s}^{-1}$ and return floods are of $3500 \mathrm{~m}^{3} \mathrm{~s}^{-1}$ (Anthony and Julian, 1999). Annual mean sediment discharge at the Var River mouth is estimated to be $1.6310^{6} \mathrm{t} \mathrm{yr}^{-1}$ using the model proposed by Mulder et al. (1997) and Mulder et al. (2001). The Var River provides mainly calcareous marl and schist. The Estéron River transports minerals such as quartz and feldspar to the river Var. In the lower valley of the Var, the river and its tributaries cross limestone and marl series of Jurassic and Cretaceous limestone. Near the mouth, river flows supply most of the pebbles found on the beaches in Nice, France.

Gravity flow activity in the canyon is believed to be controlled by the seasonal cycle of the river regime (Khripounoff et al., 2009). Several investigations, based on the interpretation of the sedimentary facies of turbidites deposited along the canyon and on the Var sedimentary ridge, indicate that turbidity currents are triggered by small-size retrogressive shallow failures on the upper steep slope, by large slope instabilities that become large ignitive turbidity currents or surge-type flows (e.g. 1979 failure), and by hyperpycnal flows triggered by high magnitude floods (Piper and Savoye 1993; Mulder et al. 1997; Mulder et al. 2001; Mas et al. 2010; Migeon et al. 2012). The sedimentary records show that the canyon has been continuously active since the late Pleistocene and that variation in turbidite sedimentation is controlled by variations in sediment supply and not by sea-level change (Jorry et al. 2011; Piper and Savoye, 1993).

\section{Sampling and data collection methods}

\subsection{Sampling locations}

The moorings were deployed from December 2008 to March 2009 at three stations along the axis of the Var canyon (Fig.1). The first was located at $510 \mathrm{~m}$ depth (VE), the second at 1280 $\mathrm{m}(\mathrm{VV})$ and the third (VA) was positioned at $1575 \mathrm{~m}$ just before the confluence of the Var and Paillon canyons.

\subsection{Flow of the Var River}

A time series of the hourly flow of the Var River waters was obtained at two stations (Fig.2): the Nice station (Banque nationale de données pour l'hydrométrie et l'hydrologie, HYDRO: http://www.hydro.eaufrance.fr) located $500 \mathrm{~m}$ upstream from the river mouth and the Carros station situated $35 \mathrm{~km}$ upstream from Nice on the Estéron River, a tributary of the Var River. Comparison of the flow observed at these two stations indicates the type of flood detected at Nice, triggered by localized and scattered storms or by heavy regional rainfall.

\subsection{Description of moorings and sampling}

Three different types of moorings were used during our experiment. 
The mooring at the VE station was composed of a modified Aaderaa ${ }^{R}$ RCM 11 current meter fixed at $30 \mathrm{~m}$ above the bottom (a.b.) with data recording frequency of $5 \mathrm{~min}$ and a sediment trap (PPS 4/3-Technicap ${ }^{\circledR}$ ) at $20 \mathrm{~m}$ a.b.. Settling particles were collected using cylindrical sediment traps with a sampling aperture of $0.05 \mathrm{~m}^{2}$. They were covered with a honeycomb baffle with $10 \mathrm{~cm}$ deep cells, which were $1 \mathrm{~cm}$ in diameter, and were equipped with 24 sampling bottles. The duration of the sampling was 7 days. The sediment trap at the shallower VE station overflowed at the beginning of the experiment during the first high river discharge, an event that produced extreme values of particle mass flux.

Before the mooring deployments, the sampling bottles of the sediment traps were filled with filtered seawater and sodium borate-buffered formalin to a final concentration of $3 \%$. Once in the laboratory, the contents of each sampling bottle from the sediment traps was examined under a dissecting microscope to sort and count the organisms and also to estimate the composition and the size of particles. The remaining particles were then rinsed with Milli- $Q$ purified water $(\mathrm{pH} \sim 7)$, freeze-dried and weighed. Total sulfur, nitrogen and carbon were determined in duplicate using a Leco CNS-2000 auto-analyzer. The organic carbon concentration was measured with a Leco WR12 elemental analyzer after removing carbonates with a $2 \mathrm{~N} \mathrm{HCl}$ solution (Weliky et al., 1983). Inorganic carbon content was estimated as the difference between total and organic carbon.

At the VV station, two moorings were deployed. The first was equipped with a downwardsfacing RDI@ $300 \mathrm{kHz}$ ADCP and positioned at $35 \mathrm{~m}$ a.b.. It recorded a current vertical profile every $30 \mathrm{~min}$. A vertical bin size of $3 \mathrm{~m}$ was used to provide horizontal and vertical current speed and direction at 10 elevations from $30 \mathrm{~m}$ down to $3 \mathrm{~m}$ a.b.. This equipment was coupled with a sediment trap (PPS 4/3, 24 sampling bottles) deployed at 10m above the current meter and two turbidity-meters attached $15 \mathrm{~m}$ below the ADCP. Two TBD turbiditymeters (instantaneous measurements of back scattering light and pressure recorded every $30 \mathrm{~min}$ ) were attached directly to the mooring cable at $15 \mathrm{~m}$ below the $300 \mathrm{kHz}$ ADCP. These turbidimeters were not calibrated and were used to obtain only qualitative information on particle concentration.

The second mooring was equipped with an RDI® $75 \mathrm{kHz}$ ADCP deployed at $300 \mathrm{~m}$ a.b., also downwards-facing. It had a vertical bin size of $5 \mathrm{~m}$ and recorded the current speed and direction every $5 \mathrm{~min}$ at 48 elevations from $215 \mathrm{~m}$ to $5 \mathrm{~m}$ a.b.. This mooring was anchored on both walls of the canyon in order to maintain the current meter at a centered position and avoid any entrainment or tilting by the flows.

The VA station was equipped with a RCM 8 current-meter (Aanderaa) at $30 \mathrm{~m}$ a.b. with a data recording frequency of 30 min and a sediment trap (PPS 4/3, 24 sampling bottles) $10 \mathrm{~m}$ below the current meter.

All the current, temperature and pressure sensors were calibrated at the IFREMER-Brest calibration laboratory.

\subsection{Quantification of integral parameters: flows and their horizontal extent}

Vertical profiles of horizontal velocity were parameterized by representative integral values (or mean values) of horizontal speed and current thickness. Integral velocity $U$, or mean velocity, and integral thickness $\mathrm{H}$ are defined and estimated as follows: 


$$
\begin{aligned}
& \mathrm{U}(\mathrm{t}) \equiv \frac{\int_{0}^{+\infty} \mathrm{u}^{2}(\mathrm{z}, \mathrm{t}) \mathrm{dz}}{\int_{0}^{+\infty} \mathrm{u}(\mathrm{z}, \mathrm{t}) \mathrm{dz}}=\frac{\sum_{\mathrm{i}-1}^{\mathrm{i}-\mathrm{i} \max } \mathrm{u}_{\mathrm{i}}^{2}(\mathrm{t}) \delta_{z_{\mathrm{i}}}}{\sum_{\mathrm{i}=1}^{\mathrm{i}-\mathrm{imax}} \mathrm{u}_{\mathrm{i}}(\mathrm{t}) \delta_{z_{\mathrm{i}}}} \\
& \mathrm{H}(\mathrm{t}) \equiv 2 \cdot \frac{\int_{0}^{+\infty} z \cdot u(z, t) d z}{\int_{0}^{+\infty} \mathrm{u}(\mathrm{z}, \mathrm{t}) \mathrm{dz}}=2 \cdot \frac{\sum_{\mathrm{i}-1}^{\mathrm{i}-\mathrm{i} \max } z_{\mathrm{i}} \cdot \mathrm{u}_{\mathrm{i}}(\mathrm{t}) \delta_{z_{i}}}{\sum_{\mathrm{i}=1}^{i-i \max } \mathrm{u}_{\mathrm{i}}(\mathrm{t}) \delta_{z_{i}}}
\end{aligned}
$$

In these formulas, $U$ is the mean horizontal velocity at a given time instant $t$, and $u(z, t)$ is the horizontal velocity at the same time $t$ and at a distance $z$ above the bottom limit of the profile. The coordinate $z$ is hence defined positive upwards. In practice, $U$-velocity and the thickness $\mathrm{H}$ are estimated from the observed values $\mathrm{u}_{\mathrm{i}}$ at the central positions $\mathrm{z}_{\mathrm{i}}$ of each i-bin of thickness $\delta z_{\mathrm{i}}$. For the data obtained with the long range $75 \mathrm{kHz} A D C P$, there were 48 bin with a bin-thickness of $5 \mathrm{~m}$.

The integral parameters are useful for the description and for the interpretation of the flows. The integral thickness $\mathrm{H}$ provides a quantitative estimate of the vertical scale of the flows. The integral velocity $U$ provides a quantitative estimate of the effective horizontal displacement of the particles in the flow as turbulent mixing and displacement modulate and involve instantaneous and local velocities.

The time series of the estimated mean velocity $U(t)$ can be to perform an Eulerian transformation of the data. This Eulerian transformation provides a spatial view of the turbidity current based on the estimated relative distance between two consecutive observations (with observed time delay and velocity) at a fixed point at VV station. Based on an arbitrary position $\mathrm{x}_{0}\left(\mathrm{x}_{0}=0\right)$ at arbitrary initial time $\mathrm{t}_{0}\left(\mathrm{t}_{0}=0\right)$ for the first velocity profile $\mathrm{u}\left(\mathrm{z}, \mathrm{t}_{0}\right)$ and corresponding mean velocity $\mathrm{U}\left(\mathrm{t}_{0}\right)$, a spatial distribution of the profiles, or a relative distance between profiles, can be obtain by an Eulerian change of coordinates:

$$
\mathrm{x}(\mathrm{t})=\mathrm{x}_{0}+\int_{\mathrm{t}_{0}}^{\mathrm{t}} \mathrm{U}\left(\mathrm{t}^{\prime}\right) d \mathrm{t}^{\prime}
$$

For instance, the time dependent vertical profile of horizontal velocity is:

$$
u(x, z)=u(x(t), z)=u(z, t)
$$

\section{Results}

Data obtained using the current meters (Table 1) indicated that all three stations were dominated by the semi-diurnal tidal period. The transport system, as described by the current characteristics, varied along the canyon. At the two most seaward stations ( $\mathrm{V}$ and VA) the east-west Liguro-Provençal current dominates and crosses the canyon axis (Fig. 3). Conversely, at the shallower VE station, an opposite-trending current flowed eastward. 
The three flood events of the Var River that were observed during the mooring deployments are summarized in Figure 2. Two of them, with a Var River flow of $>600 \mathrm{~m}^{3} \mathrm{~s}^{-1}$, coincided with observed gravity flow events (15 December 2008 and 8 February 2009) in the canyon while the third (20 January), with a flow of $230 \mathrm{~m}^{3} \mathrm{~s}^{-1}$ did not have any observable impact in the Var canyon. Conversely, two gravity flow events were observed in the canyon only at the VV station (5 February) and at the two most seaward stations (VV and VA) (18 February) without any association with river discharge. The analysis of wind intensity during these events did not show a relationship between the meteorological conditions and the triggers of these events.

\subsection{The 15-17 December 2008 events}

In mid-December, the Var River was in flood, characterized by a rapid increase in the Var river flow (Fig. 4) and began on 14 December at 9:00 with a maximum flow of $610 \mathrm{~m}^{3} \mathrm{~s}^{-1}$ at 3:00 on 15 December. The flood gradually ebbed and effectively ended $20 \mathrm{~h}$ later.

At the shallowest VE station (510 $\mathrm{m}$ depth), the flood induced several current speed fluctuations with two peaks reaching $33 \mathrm{~cm} \mathrm{~s}^{-1}$ (duration $1.5 \mathrm{~h}$ ) and $34 \mathrm{~cm} \mathrm{~s}^{-1}$ (duration $1 \mathrm{~h}$ ) within a $4 \mathrm{~h}$ interval (Fig. 4). No delay was recorded between the maximum of the flood and the current speed peaks during this event. The current direction turned from the northeast to southeast $\left(206-210^{\circ}\right)$ in the canyon axis at this station. Temperature increased by less than $0.1^{\circ} \mathrm{C}$ (Fig. 4). Smaller surges in activity were observed later, at 14:00, 22:50 and 23:30. Finally, the last major current peak was observed the 16 December at 23:30 with a speed of $13.2 \mathrm{~cm} \mathrm{~s}^{-1}$. This current took an unusual direction of $95^{\circ}$ and showed a peculiar temperature decrease of $0.02^{\circ} \mathrm{C}$. Unfortunately, due to this event, the sediment trap was filled with a large quantity of material thereby causing its malfunction.

At the middle station (VV, $1220 \mathrm{~m}$ depth), the effect of the event was also clearly observed (Fig.4). The data obtained from the $75 \mathrm{kHz}$ and $300 \mathrm{kHz}$ ADCP current meters showed that the gravity flow on 15 December, as at the VE station, was bimodal with two peaks of speed at 4:00 and 8:00 (maximum speed respectively 25.6 and $40.8 \mathrm{~cm} \mathrm{~s}^{-1}$ at $3 \mathrm{~m}$ a.b. and respectively 25.2 and $32.2 \mathrm{~cm} \mathrm{~s}^{-1}$ at $30 \mathrm{~m}$ a.b.) lasting $8 \mathrm{~h}$ and a small peak which was observed $3 \mathrm{~h}$ later with a maximum speed of $13.7 \mathrm{~cm} \mathrm{~s}^{-1}$. A third large peak was observed 2 days later (17 December at 8:00) and it lasted 4.5h with a maximum speed of $27.2 \mathrm{~cm} \mathrm{~s}^{-1}$. During these events, the current was oriented $150-160^{\circ}$ like the main axis of the canyon at this station. The $30 \mathrm{~m}$ profiles of horizontal velocity obtained with the $300 \mathrm{kHz}$ ADCP during the two first peaks on 15 December (Fig. 5) were similar from 3 to $30 \mathrm{~m}$ a.b. indicating that the event did not have any observable vertical structure at this scale and time interval record. The vertical extent of the cloud, measured with the $75 \mathrm{kHz}$ ADCP reached $130 \mathrm{~m}$ elevation at its maximum. The vertical velocity during the event (Fig. 5) indicates a strong downward orientation with a maximum of $-3.4 \mathrm{~cm} \mathrm{~s}^{-1}$ in the downward part of the flow when the horizontal velocity was at its maximum at the head of the event. Velocity decreased rapidly in the water column and with time. It became positive at the tail of this first gravity flow, but it was interrupted by a second small event which changed the vertical velocity direction. At the end of the flow, the vertical current was oriented upward, particularly in the upper layers (Fig 5). A clear positive temperature anomaly $\left(>0.2^{\circ} \mathrm{C}\right)$ was measured at $15 \mathrm{~m}$ below the $300 \mathrm{kHz}$ ADCP (Fig. 4). The entire duration of the 15 December event was $22 \mathrm{~h}$, the 17 December event lasted $15 \mathrm{~h}$. The 15 December gravity flow was also characterized by a very high peak of particle flux (Fig.6) which varied from $3 \mathrm{~g} \mathrm{~m}^{-2} \mathrm{~d}^{-1}$ during the quiet period to more than $120 \mathrm{~g}$ $\mathrm{m}^{-2} \mathrm{~d}^{-1}$ at the maximum of the event. Conversely and concurrently, the organic carbon concentration decreased from 1.7 to $0.8 \%$. The lithological composition of this material was dominated by calcite and quartz with abundant particles from $25-100 \mu \mathrm{m}$ in size. Pieces of plant remains were rare. 
Unfortunately, at the deepest and most seaward station (VA, $1575 \mathrm{~m}$ depth), the current meter was not working during these events. Temperature changes constituted the first signals of the turbidity episode passing through the canyon and resulted in increases of about $0.1^{\circ} \mathrm{C}$ (Fig. 4). In addition, current orientation varied from north to southwest at 17:20 for a duration of about $17 \mathrm{~h}$. An increase in particle flux also occurred concomitantly with the event increasing from 2 to $28 \mathrm{~g} \mathrm{~m}^{-2} \mathrm{~d}^{-1}$ along with a decrease in organic carbon from 2 to $0.9 \%$. Particles, as at the VV station, were composed of small fragments of calcite with frequent plant debris.

\subsection{The $\mathbf{5}$ and 8 February 2009 events}

On 5 February, a gravity flow was only observed at the $\mathrm{V}$ station indicating a very local event. It was characterized by a rapid increase in speed of up to $35 \mathrm{~cm} \mathrm{~s}^{-1}$ at $3 \mathrm{~m}$ a.b when the Var flood had not yet started.

The Var River was flooded on 7 February with a maximum flow of $640 \mathrm{~m}^{3} \mathrm{~s}^{-1}$. On 8 February at the VE station, current speed (30 m a.b.) increased for $1.5 \mathrm{~h}$ with a maximum of $30.5 \mathrm{~cm} \mathrm{~s}^{-1}$ and a main direction of $210^{\circ}$ (Fig 7). No major temperature anomalies were recorded during this time.

At the VV station, the major event was measured at 12:30 on 8 February at $3 \mathrm{~m}$ a.b. (maximum speed $63 \mathrm{~cm} \mathrm{~s}^{-1}$ ). At the same time, speed was only $13 \mathrm{~cm} \mathrm{~s}^{-1}$ indicating a very strong gradient of vertical velocities in the water column covered by the $300 \mathrm{kHz}$ ADCP (Fig 5). The maximum vertical extent did not exceed $50 \mathrm{~m}$ in elevation as measured with $75 \mathrm{kHz}$ ADCP during the same time interval. The profile of the vertical velocities on 8 February shows a very rapid increase in downward speed reaching $-4 \mathrm{~cm} \mathrm{~s}^{-1}$ close to the bottom (Fig 5). Curiously, positive vertical speeds were measured at higher elevations during the passage of the gravity flow body, indicating the possible discharge of material from the head of event.

During these two gravity flows ( 5 and 8 February), the current was oriented $150-160^{\circ}$, following the axis of the canyon at the $\mathrm{VV}$ station (Fig 3). The increase in temperature was noticeable $\left(0.1^{\circ} \mathrm{C}\right)$ during both events. The turbidimeters, at $15 \mathrm{~m}$ a.b. at $\mathrm{VV}$, indicated the passing of a large cloud of particles at the same time. The sedimentation of these clouds was well clearly measured by the sediment trap which indicated a particle flux increase from 2 to $98 \mathrm{~g} \mathrm{~m}^{-2} \mathrm{~d}^{-1}$ with an organic carbon concentration varying from 1.62 to $0.64 \%$ (Fig 6) at the $\mathrm{VV}$ station. The maximum flux was mainly composed of $50-100 \mu \mathrm{m}$ particles, rich in carbonate and large plant debris.

At the most seaward station, a peak of speed was recorded on 8 February with a maximum value of $25.4 \mathrm{~cm} \mathrm{~s}^{-1}$ and a main direction of $115^{\circ}$. In addition, weak negative temperature anomalies were recorded at the same moment. High particle input was measured in the sediment traps during these events with a maximum flux of $218 \mathrm{~g} \mathrm{~m}^{-2} \mathrm{~d}^{-1}$ (Fig. 6). The 5 February event was not observed at the landward VE station and was not detected at VA.

The distance between VV and VA was $7 \mathrm{~km}$ and the gravity flow took $1.5 \mathrm{~h}$ to travel between these two stations during the 8 February event. The estimated propagation speed was $1.2 \mathrm{~m}$ $\mathrm{s}^{-1}$.

\subsection{The 18 February 2009 event}

The main characteristic of the 18 February event was the total absence of any signs of Var floods or gravity current at the shallowest VE station. A major current was measured at the 
VV station with a maximum speed of $87.1 \mathrm{~cm} \mathrm{~s}^{-1}$ at $3 \mathrm{~m}$ a.b. and of $45.3 \mathrm{~cm} \mathrm{~s}^{-1}$ at $30 \mathrm{~m}$ a.b. (Fig 8). The maximum vertical extent was $90 \mathrm{~m}$ in height. Vertical velocities showed a very rapid increase in the downward speed reaching $-7.2 \mathrm{~cm} \mathrm{~s}^{-1}$ close to the bottom and $-3 \mathrm{~cm} \mathrm{~s}^{-1}$ at $30 \mathrm{~m}$ a.b. (Fig 5). At the same time at VV, current direction turned to the south-southwest (Fig.3) and the temperature increased by $0.13^{\circ} \mathrm{C}$ at 15 ma.b. (Fig 8). The particle flux reached $116 \mathrm{~g} \mathrm{~m}^{-2} \mathrm{~d}^{-1}$ during the same time. The material transported by this event was similar to that sampled during the preceding gravity flow (Fig 6).

At the deepest VA station, the same current was measured at 19:20 and it was characterized by a peak in velocity of $32.4 \mathrm{~cm} \mathrm{~s}^{-1}$, by an increase in temperature of $0.16^{\circ} \mathrm{C}$ and by particle flux reaching $137 \mathrm{~g} \mathrm{~m}^{-2} \mathrm{~d}^{-1}$ (Fig 6). It took $3 \mathrm{~h}$ for the current to travel from $\mathrm{VV}$ to VA. The calculated propagation speed was $0.64 \mathrm{~m} \mathrm{~s}^{-1}$, half the speed calculated during the 8 February event, although instantaneous speed was higher during this 18 February event. The obtained data set is summarized in the Table 1.

\subsection{Time-spacing transformation}

The resulting time-spacing transformation for each event is presented in Figure 9. The identified scales of the flows, length scale $(L)$, maximum thickness $(H)$ and velocities $(U m)$, are indicated in Table 2. The ratio between the length and the maximum thickness was estimated. The flows were divided into three main parts; a head, a body and a tail. The head is associated with the front of the flows and is considered to range from the beginning of the flow to a maximum after which the flow velocity and thickness stabilizes (the body) or decreases (the tail). Two types of longitudinal profiles were identified : Short events (8 February) that present a quick decay in speed behind the head and long events (15 December and 18 February) that present a head, a body and a tail in which their longitudinal scale is much larger then their maximum thickness. Their thickness to length ratio is of the order of $2 \%$. For the short event, the maximum thickness of the flows occured after the head and the maximum of basal velocity; the vertical gradients of horizontal velocity were not clearl. The other two events (15 December and 18 February) showed a well-developed longitudinal scale. At $7 \mathrm{~km}$ long, the 18 February event presented a defined structure with clear vertical gradients and a maximum thickness at the head and associated with the maximum basal velocity. The vertical scale of the flows was up-limited to between 100 and $150 \mathrm{~m}$.

\section{Discussion}

\subsection{Gravity flow event processes}

The availability of high-frequency measurements of current speeds at several elevations using regular and ADCP current meters made it possible to record the complexity of the speed profiles during gravity flows. With data sets obtained on 15 December 2008, we can establish a detailed description of the events initiated directly by a flood in the Var River. The gravity flow was characterized by several features: a very short delay between the flood maximum and the event observed at the shallowest station, relatively low speed along the canyon and a large and homogenous vertical extent. This combination of features is typical of hyperpycnal flow (see review Mulder et al., 2003), previously described in the Var canyon (Khripounoff et al., 2009; Mas et al., 2010). In general, hyperpycnal currents are less concentrated than turbulent flows generated by slope destabilization and the vertical gradient of concentration in particles is also less pronounced (Mulder and Alexander, 2001). Laboratory experiments show that hyperpycnal flows are much slower than turbidity triggered by slide-induced surge (Alexander and Mulder, 2002). 
Temporal changes in hyperpycnal current speeds depend solely on flood intensity (Kassem and Imran, 2001). The models using the parameters of Var River flow suggest that the hyperpycnal currents, initiated by a particulate concentration of $35-40 \mathrm{~kg} \mathrm{~m}^{-3}$, require a minimal flow of $600 \mathrm{~m}^{3} \mathrm{~s}^{-1}$ (Mulder et al., 1997). This flow value was measured during the two floods of the Var River observed during this study. Although the major trigger factor for hyperpycnal currents is particle concentration, the trigger threshold of $35-40 \mathrm{~kg} \mathrm{~m}^{-3}$ can be substantially lowered by convective instability and local hydrodynamic conditions. Moreover, Parsons et al. (2001) and Felix et al. (2005), a sediment concentration of just $5 \mathrm{~kg} \mathrm{~m}^{-3}$ can be sufficient to generate hyperpycnal plunging at sea. For the Var River, this value corresponds to a flood of $300 \mathrm{~m}^{3} \mathrm{~s}^{-1}$. On 20 January, a weak flood in the Var River, with a maximum flow of $250 \mathrm{~m}^{3} \mathrm{~s}^{-1}$, did not trigger any events indicating that the quantity of suspended material transported was not sufficient to induce any gravity flow.

Because hyperpycnal fluid is initially composed of freshwater, current speed is strongly reduced by the low gradient of water densities; therefore hyperpycnal flow is much slower than slide-induced gravity flow. According to our observations, the hyperpycnal current on 15 December was synchronous with a river flood and was characterized by rapid temporal changes in speeds with several phases of acceleration and then deceleration. The most interesting feature is the low horizontal velocity compared to the very large vertical extent which was extremely homogenous and reached more than $100 \mathrm{~m}$ (Fig 10). Our moorings also showed significant increases in temperature, upstream from the canyon where the mixed waters (fresh and sea-water) were warmer. If we compare these observations with previous measurements in the Var canyon (Khripounoff et al., 2009), only four of seven described events were actually hyperpycnal currents.

Although the Var River flood on 8 February was comparable to the 15 December flood, its outcome was completely different. The hydrodynamic parameters observed during this flood episode described a typical gravity flow triggered by sediment failure. There are many studies on these types of flows and several classifications have been proposed (Mulder and Alexander, 2001; Mulder and Cochonat, 1996; Shanmugam, 2000; Stow \& Shanmugam, 1980). In our case, in situ observations indicate a turbidity puff with a short lifetime (Laval et al, 1988). The injection of material was instantaneous and there was no material supplied from the rear. This type of turbidity flow develops only one reduced body (Middleton, 1966). Turbidity currents have been observed in few natural settings, using moorings deployed in canyons or made from cable breaks. In the Congo canyon, the recorded turbidity current lasted less than $10 \mathrm{~h}$ and the speed peak was reached in less than $1 \mathrm{~h}$ (Khripounoff et al., 2003; Vangriesheim et al., 2009). In the Palamós canyon, turbidity currents lasted from 1 to 6 h (Palanques et al., 2006a) and in the Hueneme Canyon the head of the gravity flow was particularly fast (Xu et al., 2010). However, mooring instruments in a canyon is difficult and temporal changes in a turbidity current speed are not often observed.

In this study, we suggest that the 8 February event was the result of a sediment landslide close to the mouth of the river characterized by fast-transport of material. The delay between the flood maximum and the peak of speed current at the VE station was about $36 \mathrm{~h}$. However, the relationship between the Var flood and the event cannot be disregarded. Several scenarios can be proposed: the meteorological conditions (storm localization on the Var drainage basin and sea conditions) were not sufficient to reach the critical threshold of particle concentration to trigger a hyperpycnal current, but could destabilize sediment close to the Var mouth causing a slide. The repetitive deposition of fine-grained particles by the river could lead to the formation of underconsolidated beds on steep slopes. But, no storm was observed before or on 8 February. Alternatively, flocculation of plume material could settle rapidly generating a fluid mud layer and hence cause a sediment-laden flow. However, the high peak of speed current at the VE station disproves a hyperpycnal current. 
The particularity of the 5 and 18 February events is the complete lack of association with the Var River flow or local storms. Furthermore, they were not observed at the shallower VE station on the same date. Only canyon-wall slumping between the VE and VV stations can generate local near-bed sediment plumes and turbidity currents. The temperature increases of $0.2-0.4^{\circ} \mathrm{C}$ during the current speed peaks and indicates a direct upslope origin probably close to the coast.

All events observed in February were typical turbidity currents with very sharp gradients in horizontal velocity as described in the Congo canyon (Khripounoff et al., 2009; Vangriesheim et al., 2009) and in the Hueneme and Mugu canyons (Xu et al., 2010). The result of these collapses is turbidity currents with high and very pronounced vertical gradient velocity.

In the light of our results, the conclusions drawn by Khripounoff et al. (2009) on several events recorded in Var canyon between 2005 and 2008 can be re-interpreted. All of the submarine gravity flows observed during this period were described as hyperpycnal currents due to the occurrence of the Var floods and the gravity flow events. However, a detailed reanalysis of the data shows that at least two events were probably not hyperpycnal currents but turbidity puffs because the time interval between the flood and the gravity flow was too long and the current speeds were too fast.

The difference between the gravity flows observed in this study is likely to be related to the nature of the sediment sources. Homogeneous events are related to diluted sources (hyperpycnal event) and resuspension of fresh deposits. Stratified events are related to concentrated and near bottom landslides.

\subsection{Structures of gravity flows}

By convention, gravity flow can be described in three parts: the head of the flow which is defined by a rapid increase in velocity at the flow front, the body of the flow is a longer period of relatively strong flow deceleration and the transition between the body and tail of the flow is defined as a more gradual flow deceleration. This transition corresponds to the beginning of the waning tail of the flow (see review by Kneller and Buckee, 2000).

From our high-frequency data on currents obtained at the shallowest VE station (30 m a.b.) located near the trigger of the events, we observed that the head of the gravity passed very quickly, in about $5 \mathrm{~min}$. The strong deceleration observed just after the head may relate to the presence of an eddy at the rear of the head as described in tank experiments (Choux et al., 2005). Then, the body of the flow began with another increase in velocity and a more gradual flow deceleration with nonetheless several peaks of speed within the body. This transition corresponds to the beginning of the waning tail of the flow; flow velocity gradually decreased at all levels. In general terms, the high- and low-density flows have similar timedependent velocity structure. In detail, however, there were important differences. Dense flow was thinner and traveled faster than dilute flow, with a shorter head. The height of maximum velocity was lower for high-density flow than for low-density flow which is in agreement with previous experiments (Choux et al., 2005; Kneller et al., 1999).

The 3D representation (Fig. 10) of horizontal velocity shows maximum values at the front of the head and progressively the flow deceleration with the increasing distance behind it. The decrease in velocity in the tail is particularly noticeable. The fact that the low- and highdensity flows were non-uniform implies that it is impossible to deduce the structure of flows based only on studies of time-series data obtained at just location or just one elevation. For example, the current data at VE which, despite the very high frequency measurements, cannot be used to define the various observed events because the observation was recorded only at one elevation. The ADCP current meter can now be considered as a useful 
instrument for studying gravity flow (Xu et al., 2010). For instance, vertical velocities measured with the ADCP show that the events had a strong vertical speed component like a road roller. The vertical current analysis also revealed the overpressure at the front of the gravity flow at the record of the 5 February event, demonstrated by a clear positive vertical current appearing just before this weak gravity flow (Fig. 5).

Temperature can be another useful parameter for gravity flow studies, because it translates the passage of turbid water coming from shallower water. Regarding temperature variation in the water column in the Mediterranean Sea (Marty et al., 2002), the water mass coming from surface is warmer than water from the depths. For example, Johnson et al. (2001) noted an increase in temperature of $0.7^{\circ} \mathrm{C}$ in their station at $1200 \mathrm{~m}$ depth where a hyperpycnal current originated from a flood in the Salinas River.

Nevertheless, Palanques et al. (2006b) detected only a weak increase in temperature (between 0.02 and $0.09^{\circ}$ ) during the turbidity current initiated at about $600-700 \mathrm{~m}$ where the temperature was not very different. In Mugu and Hueneme canyons, at less than $200 \mathrm{~m}$ depth, temperatures increased more than $2^{\circ} \mathrm{C}$ during an episodic turbidity current (Xu et al., 2010). However, analyzing flows based on temperature is difficult when turbulence or mixing with surrounding water strongly influences the local environment. Thus, in our stations, we generally noted an increase in temperature during gravity flows, with one exception on 8 February when temperature decreased significantly at the VE and VA stations. In winter, river water is colder and coastal water temperature can be affected by cool winds and become colder than deep water. Temperature variations were sometimes particularly strong at the VV station but were always rather weak at the VE and VA stations.

\subsection{Particle transport}

Data obtained from the sediment traps indicate that, increases in current speed correspond to an increase in particle flux. However, the sampling interval was too great (7 days per sample) to describe in detail the role of the gravity flow in particle transport. Likewise, the use of sediment traps in a high-energy environment is not advised for a quantitative approach for two reasons. First, this equipment is primarily designed to measure vertical particle fluxes and is disrupted when the mooring tilts due to strong currents. Second, material transport in gravity flow is essentially horizontal and cannot directly enter in the trap. However, despite these limitations, sediment traps in a canyon remain useful for a qualitative study of the transported sediment (Xu et al., 2010). The gravity flow on 15 December was determined to be a hyperpycnal current with relatively low speed, and we therefore assume that the artifacts produced by horizontal transport were minor. Particle flux at VA station was lower than at VV in regard to the loss of material during transport (Fig. 6). Conversely, during the more energetic February events, the sediment traps could not easily catch the settling material, especially at VV. As a result, the measured particle fluxes were higher at the deepest VA station than at VV. With respect to the previous measurements obtained using the same equipment in the Var canyon (Khripounoff et al., 2009), the present particle flux data from VV are comparable (about $0.8 \mathrm{~g} \mathrm{~m}^{-2} \mathrm{~d}^{-1}$ ). However, some differences were observed at VA with a flux of $1.4 \mathrm{~g} \mathrm{~m}^{-2} \mathrm{~d}^{-1}$ during the 8 February event, for example. This value is 10 times higher than the flux measured during 2005-2008 period, indicating that the gravity flow has complex behavior. The material transported by these events is not influenced solely by horizontal velocity or river flood intensity.

The estimation of the integral mean speed and of the integral thickness of the flows may provide information on the amount of sediment (or potential energy) necessary to sustain the flow. Considering quasi-stationary conditions and hence that square friction-induced deceleration balances the acceleration by density differences, the integral velocity is: 


$$
C_{D} \cdot U^{2}=g R \phi H \cdot \sin (\alpha)
$$

where $C_{D}$ is the friction coefficient depending on the Reynolds number of the flow and the roughness of the canyon floor, $g$ is the gravity acceleration, $R$ modulates the gravity due to the density contrast between sediment particles and the surrounding water, $\phi$ is the volumetric sediment concentration of the suspension, $\mathrm{H}$ is the integral thickness of the flow and $\alpha$ is the angle of the slope.

The density parameter $\mathrm{R}$ is a constant estimated on the basis of a density of sediment particles of $2600 \mathrm{~kg} \cdot \mathrm{m}^{-3}$, and a density of the ambient water of $1035 \mathrm{~kg} \cdot \mathrm{m}^{-3}$, and considering the suspension is very diluted $(\phi<<1)$ :

$$
R=\frac{\left(\rho_{s}-\rho_{0}\right)}{\left[\rho_{0}+\left(\rho_{s}-\rho_{0}\right) \cdot \phi\right]} \approx \frac{\left(\rho_{s}-\rho_{0}\right)}{\rho_{0}} \approx 1,51
$$

The value of the friction coefficient $C_{D}$ depends on the roughness of the canyon floor for well developed turbulent flows. The bulk Reynolds number of the flows based on both integral parameters is fairly high $\left(R_{\mathrm{e}} \sim 10^{7}\right)$. The $\mathrm{VV}$ station is located in an area of the canyon where well developed gravel waves are present (Klaucke et al., 2000 ; Malinverno et al., 1988), the absolute roughness ranges from 1 to $10 \mathrm{~m}$. Considering the integral thickness of the flows $(\sim 100 \mathrm{~m})$, the friction coefficient $C_{D}$ is hence estimated to range from $1.10^{-2}$ to $10.10^{-2}$. The angle of the slope in the canyon is estimated to be $2.25^{\circ}(\sin (\alpha)=0,04)$ between 1400 and $1600 \mathrm{~m}$ depth (5100 $\mathrm{m}$ of horizontal displacement between both depths).

From these considerations the dry sediment concentration can be estimated by:

$$
\mathrm{C}=\rho_{\mathrm{s}} \cdot \phi=\rho_{\mathrm{s}} \cdot \frac{\mathrm{C}_{\mathrm{D}} \cdot \mathrm{U}^{2}}{\mathrm{gRH} \cdot \sin (\alpha)}
$$

The head and the body of turbidity currents travel at different speeds. At the head of the flows, the slope driven stationary solution does not apply and the flow is transient. The pressure gradient at the front of the flow depends mainly on the density contrast between the flow and the ambient water, and on the thickness of the flow. At the front the pressure gradient is balanced by the transient momentum or inertia term. At the front, the balance between both terms may be written as follows:

$$
H \cdot U^{2}=\frac{1}{2} g R \phi \cdot H^{2}
$$

The left hand side term represents total momentum contrast at the front; the right hand side term represents the hydrostatic pressure due to sediment concentration. Extracting the head speed from this equation provides the well-known head speed equation (Altinakar, 1998):

$$
U=0.71 \sqrt{g R \phi \cdot H}
$$

When the head equation applies, the dry sediment concentration is related to the integral parameters (speed and thickness) by the following equation:

$$
\mathrm{C}=\rho_{\mathrm{S}} \cdot \phi=\rho_{\mathrm{S}} \cdot \frac{2 \mathrm{U}^{2}}{\mathrm{gR} \cdot \mathrm{H}}
$$


Figure 11 shows the temporal change in the estimated sediment concentration for the observed events on the basis of both head and body driving equations, considering a friction coefficient $C_{D}$ of $1.10^{-1}$, equivalent to an absolute roughness of $7 \mathrm{~m}$ (Klaucke et al., 2000). Table 2 presents characteristic values for each event of maximum sediment concentration, induced shear stress and associated critical grain size for sediment transport and maximum vertical settling fluxes. An equivalent 7-day flux is computed in order to compare computed fluxes to data from sediment traps. Computed dry sediment concentrations for both the body and the head have different values, but their orders of magnitude (mainly in the head to body transition) are of the same order of magnitude. The 15 December event shows a similar sediment concentration of $0.5 \mathrm{~g} \mathrm{l}^{-1}$ at the head and at the detached body. The 18 February event has a more than doubled concentration at its maximum value, over $1.5 \mathrm{~g} \mathrm{l}^{-1}$ followed by a quick decay. This strong decay was observed for all events when the mean concentration dropped below $0.1 \mathrm{~g} \mathrm{l}^{-1}$ with the exception of the weaker 8 February event where sediment concentrations seldom reached this value. The duration of the events seems to be controlled by the amount of sediments in suspension and the potential energy they provide. The flows are sustained if the settling flux from suspension is compensated by erosion and remobilization. They decay rapidly because the sediment concentration is insufficient to sustain the flow and remobilize sediments underneath.

Due to the extreme roughness of the canyon (and hence the value of $C_{D}$ ), the turbulent mixing is fairly high (from $10^{-3}$ on 8 February to $2.10^{-2}$ on 18 February) (Fig .12). Hence, the bottom friction due to the observed maximum velocities is few Pascals (8 February) to several tens of Pascals (18 February). These values are sufficient to mobilize sediments where grain size ranges from tens of $\mathrm{mm}$ to several $\mathrm{cm}$, bottom sediments may be gravel or coarser. The VV station is a by-pass zone for the observed flows.

Vertical sediment settling can be computed on the basis of a settling velocity model for the particles. There is no data to propose such a model for the Var sediments. Considering the settling model proposed by Thorn, (1981) for estuarine sediments, the settling velocity $\left(w_{s}\right)$ increases with sediment concentration $\mathrm{C}$ due to flocculation processes:

$$
\mathrm{W}_{\mathrm{s}}=\mathrm{k} \mathbf{C}^{\alpha}
$$

In this equation $\mathrm{k}$ and $\alpha$ are empirical parameters. For the Thorn model (1981), these parameters are respectively 0.51 and 1.29 , corresponding to a settling velocity of $2.10^{-2}$ $\mathrm{mm} . \mathrm{s}^{-1}$ for low sediment concentrations of $0.1 \mathrm{~g} \mathrm{l}^{-1}$ and $0.5 \mathrm{~mm} \mathrm{~s}^{-1}$ at a concentration of $1 \mathrm{~g} \mathrm{I}^{-1}$.

This realistic model was used to estimate the order of magnitude of the vertical sediment flux. For the 18 February event the estimated vertical settling reached a maximum value of $5.10^{4} \mathrm{~g} \mathrm{~m}^{-2} \mathrm{~d}^{-1}$. The mean flux over $12.5 \mathrm{~h}$ was of $4.10^{3} \mathrm{~g} \mathrm{~m}^{-2} \mathrm{~d}^{-1}$. The total amount of the settling sediments during this single event corresponded to a mean flux of $300 \mathrm{~g} \mathrm{~m}^{-2}$ day $^{-1}$ over 7 days. The settling flux recorded by the sediment-trap at the VV station during the same period gives a value around $120 \mathrm{~g} \mathrm{~m}^{-2} \mathrm{~d}^{-1}\left(220 \mathrm{~g} \mathrm{~m}^{-2} \mathrm{~d}^{-1}\right.$ at VA station). Considering the simplifications on the basis of the estimated values and the limits of sediment traps to effectively sample all the settling flux, this estimation is on the same order of magnitude of those the recorded fluxes. Equivalent calculations for the 15 December events provide mean settling fluxes over 7 days of $21 \mathrm{~g} \mathrm{~m}^{-2} \mathrm{~d}^{-1}$ when the recorded flux is of 50 to $100 \mathrm{~g} \mathrm{~m}^{-2} \mathrm{~d}^{-1}$ at VV. Meanwhile, the 15 December event was related to a flood and it was not an isolated event as was the 18 February event.

Elemental composition of material transported by flow events depends on the origin of the sediment carried in the gravity flow. During periods of large material transport in the Mugu and Hueneme canyons, reworked sediments, rather than newly introduced river-borne sediments, were the suggested origin of most of the material entering these canyons during 
storms (Xu et al., 2010). Flash floods in the Var River are generated by violent storms which erode the calcareous sub-alpine mountain (French Alps). Floods typically transport material rich in limestone, similar to the particles sampled during the events. The enrichment in inorganic carbon of particles transported by the gravity flows did not vary in regard to the type of events: hyperpycnal currents or turbidity currents were fundamentally composed of the same material coming from soil erosion of the Var River banks. We also note that there was very little pelagic material in the sediment trap samples because pelagic particles were completely diluted in the bulk of gravity flow material. Gravity flows also control the organic input in the canyon. The visual observation of particles sampled by the sediment traps indicates several differences in composition during the events. For example, the hyperpycnal current was more enriched in plant debris than the turbidity landslide current. However, this observation was not corroborated in terms of organic carbon concentration. As a general rule, although it can be an important element in the sediment mass balance of oceans, material from the continent is impoverished in organic carbon compared to the pelagic particles settling from the sea surface. It is estimated that small rivers in southern Europe (excluding the Var River) discharge more than $140 \mathrm{Mt}$ of sediment (Milliman and Syvitski, 1992). The sum of these inputs to the deep oceans cannot be minimized in global-scale biogeochemical fluxes especially in terms of carbon.

\section{Conclusion}

Current and sediment trap measurements are useful tools to determine the mechanism of the gravity flow triggering and to distinguish sediment failure from hyperpycnal currents. According to our observations and criteria given in the literature, hyperpycnal currents occur synchronously with river floods and are characterized by temporal changes in speeds presenting one or more phases of acceleration and then deceleration, and by a significant increase in temperature. In contrast, sediment failure can be initiated outside of flood periods (or shortly thereafter) and downstream from the river mouth. They are characterized by temporal changes in speed that show a rapid increase corresponding to the passage of the head then a regular decrease, and by a very weak increase in temperature. The difference between gravity flows is interpreted as related to the nature of the sediment sources. Hyperpycnal flow seems to be triggered when the Var River discharge reaches or surpasses $600 \mathrm{~m}^{3} \mathrm{~s}^{-1}$. Gravity flows due to sediment landslide seem less related to river flow and its occurrence and flow characteristics are random.

The estimated sediment concentration of the flows, calculated on the basis of the gravity flows equations, is fairly low (mainly between 0,5 to $1 \mathrm{~g} \mathrm{I}^{-1}$ ). These diluted suspensions may develop over a thickness of $100 \mathrm{~m}$. This result can be interpreted as a balance between turbulent flow of ambient water and particles settling. The flows are capable for transporting capability for sediments as coarse as gravel, which are the main deposits in the canyon and supports the idea that the canyon behaves as a bypass. Finer particles, such as those in suspension, may settle on the canyon floor at the end of each flow, but are remobilized event after event.

The consequences of gravity flows described in this work do not seem significantly influence sediment deposition or canyon morphology. Low-magnitude, high-frequency events, such as yearly hyperpycnal currents, are confined to the upper part of the system and thus have little control over system architecture (Mas et al, 2010). When the gravity flow ends, some of the transported particles settle on the bottom. However, the next event erases this fine sediment layer and prevents any historical record in the sediment. Only high-magnitude gravity flow with spill over and major events such as earthquakes or tsunami seems to leave failure scars on the canyon (see review of landslides of the Ligurian margin by Migeon et al, 2011). 
Future investigations in the Var canyon would help to describe the different types of gravity flow and determine how they are formed, as done in the study by Warrick et al. (2008). With high-resolution measurements of currents using ADCP records, vertical velocity could be analyzed, involving turbulence intensity at different elevation in the gravity current. Zones of high turbulence are associated with the front and base of the flows. There are many questions that remain to be addressed, what are the grain-size and geochemical characteristics of sediment in these transport events and how do these events influence marine sediment budgets? Recent research has shown that small mountainous river systems account for a significant fraction of the global flux of sediment and particulate organic carbon to the ocean (Wheatcroft et al., 2010). The work presented here and elsewhere (Khripounoff et al., 2009) have offered evidence that these gravity flows occur somewhat frequently (1 to 3 year recurrence rate) in the Var canyon and are an important factor in the sediment mass balance of material coming from a mountain river. Future studies will reveal further details of the formation, the nature, and the impact of these gravity flows.

\section{Acknowledgements}

We thank the captains and crews of the R/V Europe and R/V Tethys. The scientific and technical staffs participating in the IFREMER- Solveig program are also warmly acknowledged.

\section{References}

Alexander, J., Mulder, T., 2002. Experimental quasi-steady density currents. Marine Geology $186,195-210$.

Altinakar, M.S. (1998). Fluvial Hydraulics, flows and transport processes in channels of simple geometry. In W.H. Graf. (p. 682): John Wiley and Sons.

Anthony, E.J., Julian, M., 1999. Source-to-sink sediment transfers, environmental engineering and hazard mitigation in the steep Var River catchment, French Riviera, southeastern France. Geomorphology 31, 337-354.

Choux, C.M.A., Baas, J.H., McCaffrey, W.D., Haughton, P.D.W., 2005. Comparison of spatio-temporal evolution of experimental particulate gravity flows at two different initial concentrations based on velocity, grain size and density data. Sedimentary Geology 179, 4969.

Felix, M., Sturton, S., Peakall, J., 2005. Combined measurements of velocity and concentration in experimental turbidity currents. Sedimentary Geology 179, 31-47.

Garcia, M., Parker, G., 1989. Experiments on hydraulic jumps in turbidity currents near a canyon-fan transition Science 245.

Gardner, W.D., 1989. Periodic resuspension in Baltimore Canyon by focusing of internal waves. Journal of Geophysical Research 94, 18185-18194.

Johnson, K.S., Paull, C.K., Barry, J.P., Chavez, F.P., 2001. A decadal record of underflows from a coastal river into the deep sea. Geology 29, 1019-1022. 
Jorry, S.J., Jégou, I., Emmanuel, L., Silva Jacinto, R., Savoye, B., 2011. Turbiditic levee deposition in response to climate changes: The Var Sedimentary Ridge (Ligurian Sea). Marine Geology 279, 148-161.

Kassem, A., Imran, J., 2001. Simulation of turbid underflows generated by the plunging of a river. Geology 29, 655-658.

Khripounoff, A., Vangriesheim, A., Babonneau, N., Crassous, P., Dennielou, B., Savoye, B., 2003. Direct observation of intense turbidity current activity in the Zaire submarine valley at 4000m water depth. Marine Geology 194, 151-158.

Khripounoff, A., Vangriesheim, A., Crassous, P., Etoubleau, J., 2009. High frequency of sediment gravity flow events in the Var submarine canyon (Mediterranean Sea). Marine Geology 263, 1-6.

Klaucke, I., Savoye, B., Cochonat, P., 2000. Patterns and processes of sediment dispersal on the continental slope off Nice, SE France. Marine Geology 162, 405-422.

Kneller, B.C., Bennett, S.J., McCaffrey, W.D., 1999. Velocity structure, turbulence and fluid stresses in experimental gravity currents. Journal of Geophysical Research 104, 5381- 5391.

Kneller, B.C., Buckee, C., 2000. The structure and fluid mechanics of turbidity currents: a review of some recent studies and their geological implications. Sedimentology 57, 62-94.

Laval, A., Cremer, M., Beghin, P., Ravenne, C., 1988. Density surges: Two-dimensional experiments. Sedimentology 35, 73-84.

Lee, H.Y., Yu, W.S., 1997. Experimental study of reservoir turbidity current. Journal of Hydraulic Engineering 123, 520-528.

Liu, J.T., Lin, H.-L., Hung, J.-J., 2006. A submarine canyon conduit under typhoon conditions off southern Taiwan. Deep-Sea Research 1 53, 223-240.

Malinverno, A., Ryan, W.B.F., Auffret, G.A., Pautot, G., 1988. Sonar images of recent failure events on the continental margin off Nice, France. In: H. Clifton (Editor), Sedimentological consequences of convulsive geologic events. Geological Society of America, Special Paper 229, 59-75.

Marty, J.-C., Chiavérini, J., Pizay, M.-D., Avril, B., 2002. Seasonal and interannual dynamics of nutrients and phytoplankton pigments in the western Mediterranean Sea at the DYFAMED time-series station (1991-1999). Deep-Sea Research 2 49, 1965-1985.

Mas, V., Mulder, T., Dennielou, B., Khripounoff, A., Savoye, B., 2010. Multiscale spatiotemporal variability of sedimentary deposits in the Var turbidite system (North-Western Mediterranean Sea). Marine Geology 275, 37-52.

Middleton, G.V., 1966. Experiments on density and turbidity currents: Motion of the head. Canadian Journal of Earth Sciences, 523-546.

Migeon, S., Cattaneo, A., Hassoun, V., Larroque, C., Corradi, N., Fanucci, F., Dano, A., Mercier de Lepinay, B., Sage, F., Gorini, C., 2011. Morphology, distribution and origin of recent submarine landslides of the Ligurian Margin (North-western Mediterranean): some insights into geohazard assessment. Marine Geophysical Researches 32, 225-243. 
Migeon, S., Mulder, T., Savoye, B. and Sage, F., 2012. Hydrodynamic processes, velocity structure and stratification in natural turbidity currents: Results inferred from field data in the Var Turbidite System. Sedimentary Geology, 245-246, 48-62.

Milliman, J.D., Syvitski, J.P.M., 1992. Geomorphic/tectonic control of sediment discharge to the ocean: the importance of small mountainous rivers. Journal of Geology 100, 525-544.

Mulder, T., Alexander, J., 2001. The physical character of subaqueous sedimentary density flows and their deposits. Sedimentology 48, 269-299.

Mulder, T., Cochonat, P., 1996. Classification offshore mass movements. Journal of Sedimentary Research 66, 43-57.

Mulder, T., Savoye, B., Syvitski, J.P.M. and Parize, O., 1997. Des courants de turbidité hyperpycnaux dans la tête du canyon du Var? Données hydrologiques et observations de terrain (Hyperpycnal turbidity currents at the head of the Var Canyon? Hydrological data and geological observations). Oceanologica Acta, 20(4): 607-626.

Mulder, T., Savoye, B., Piper, D.J.W., Syvitski, J.P.M. (1998). The Var submarine sedimentary system: understanding Holocene sediment delivery processes and their importance to the geological record. In M.S. Stoker, Evans, D; \& Cramp, A. , Geological Processes on Continental Margin: Sedimentation, Mass-wasting and stability, Vol. 129 (pp. 145-166). London: Geological Society, Special Publication.

Mulder, T., Savoye, B., Syvitski, J.P.M., Parize, O., 1997. Des courants hyperpycnaux dans la tête du canyon du Var. Données hydrologiques et observations de terrain. Oceanologica Acta 20, 607-626.

Mulder, T., Migeon, S., Savoye, B. and Faugères, J.-C., 2001. Inversely graded turbidite sequences in the deep Mediterranean: a record of deposits from flood-generated turbidity currents? Geo-marine letters, 21, 86-93.

Mulder, T., Syvitski, J.P.M., Migeon, S., Faugères, J.-C., Savoye, B., 2003. Marine hyperpycnal flows: initiation behavior and related deposits. A review. Marine and Petroleum Geology 20, 861-882.

Palanques, A., El Khatab, M., Puig, P., Masqué, P., Sanchez-Cabeza, J.A., Isla, E., 2005. Downward particle fluxes in the Guadiaro submarine canyon depositional system (northwestern Alboran Sea), a river flood dominated system. Marine Geology 220, 23-40.

Palanques, A., Durrieu de Madron, X., Puig, P., Fabres, J., Guillen, J., Calafat, A., Canals, M., Heussner, S., Bonnin, J., 2006a. Suspended sediment fluxes and transport processes in the Gulf of Lions submarine canyons. The role of storms and dense water cascading. . Marine Geology 234, 43-61.

Palanques, A., Martín, J., Puig, P., Guillén, J., Company, B., Sardà, F., 2006b. Evidence of sediment gravity flows induced by trawling in the Palamós (Fonera) submarine canyon (northwestern Mediterranean). Deep-Sea Research 153, 201-214.

Parsons, J.D., Bush, J.W.M., Syvitski, J.P.M., 2001. Hyperpycnal plume formation from riverine outflows with small sediment concentrations. Sedimentology 48, 465-478.

Piper, D.J.W. and Savoye, B., 1993. Processes of late Quaternary turbidity current flow and deposition on the Var deep-sea fan, north-west Mediterranean Sea, Sedimentology 40, 557582. 
Piper, D.J.W., Normark, W.R., 2009. Processes that initiate turbidity currents and their influence on turbidites: a marine geology perspective. Journal of Sedimentary Research 79, 347-362.

Sage, F., 1976. La sédimentation à l'embouchure d'un fleuve côtier méditerranéen. Doctoral Thesis, Université de Nice, 243 pp.

Shanmugam, G., 2000. 50 years of the turbidite paradigm (1950s-1990s): deep-water processes and facies models: a critical perspective. Marine and Petroleum Geology 17, 285342.

Siegenthaler, C., Buhler, J., 1985. The kinematics of turbulent suspension currents (turbidity currents) on inclined boundaries. Marine Geology 64, 19-40.

Stow, D.A.V., Shanmugam, G., 1980. Sequence of structures in fine-grained turbidites; comparison of recent deep-sea and ancient flysch sediments. Sedimentary Geology 25, 2342.

Thorn, M.F.C. (1981). Physical processes of siltation in tidal channels., Proceedings Hydraulic Modelling Applied to Maritime Engineering Problems (pp. 47-55). ICE, London.

Vangriesheim, A., Khripounoff, A., Crassous, P., 2009. Turbidity events observed in situ along the Congo submarine channel. Deep-Sea Research 2 56, 2208-2222.

Warrick, J.A., Xu, J.P., Noble, M.A., Lee, H.J., 2008. Rapid formation of hyperpycnal sediment gravity currents offshore of a semi-arid California river. Continental Shelf Research 28, 991-1009.

Weliky, K., Suess, E., Ungere, C., Muller, P., Fischer, K., 1983. Problems with accurate carbon measurements in marine sediments and water column particulates: a new approach. Limnology and Oceanography 28, 1252-1259.

Wheatcroft, R.A., Goni, M.A., Hatten, J.A., Pasternack, G.B., Warrick, J.A., 2010. The role of effective discharge in the ocean delivery of particulate organic carbon by small, mountainous river systems. Limnology and Oceanography 55, 161-171.

Xu, J.P., Swarzenski, P.W., Noble, M., Li, A.-C., 2010. Event-driven sediment flux in Hueneme and Mugu submarine canyons, southern California. Marine Geology 269, 74-88. 
Table 1: Maximum of horizontal and vertical velocity, time of observation and maximum particle flux obtained during the 4 events at the 3 stations of the Var canyon

\begin{tabular}{|c|c|c|c|c|}
\hline & Station & $\begin{array}{l}15^{\text {th }} \\
\text { December }\end{array}$ & $8^{\text {th }}$ December & $\begin{array}{l}18^{\text {th }} \\
\text { December }\end{array}$ \\
\hline 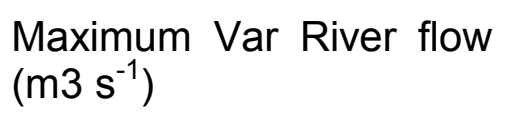 & & 610 & 640 & 53 \\
\hline $\begin{array}{l}\text { Maximum velocity at } 30 \\
\text { m altitude }\end{array}$ & $\begin{array}{l}\text { VE } \\
\text { VV } \\
\text { VA }\end{array}$ & $\begin{array}{l}34.0 \\
32.2 \\
\text { No data }\end{array}$ & $\begin{array}{l}30.5 \\
19.8 \\
25.4\end{array}$ & $\begin{array}{l}2.5 \\
45.3 \\
32.4\end{array}$ \\
\hline $\begin{array}{l}\text { Maximum velocity }\left(\mathrm{cm} \mathrm{s}^{-}\right. \\
\left.{ }^{1}\right) \text { at } 3 \mathrm{~m} \text { altitude }\end{array}$ & VV & 40.8 & 63.8 & 87.1 \\
\hline $\begin{array}{l}\text { Maximum vertical velocity } \\
\left(\mathrm{cm} \mathrm{s}^{-1}\right)\end{array}$ & VV & -3.6 & -4.6 & -7.2 \\
\hline $\begin{array}{l}\text { Maximum } \\
\text { extension }(m) \quad \text { vertical }\end{array}$ & VV & $130 m$ & $50 \mathrm{~m}$ & $90 \mathrm{~m}$ \\
\hline Time of observation (h) & $\begin{array}{l}\text { VE } \\
\text { VV } \\
\text { VA }\end{array}$ & $\begin{array}{l}04 \mathrm{~h} 34 \\
07 \mathrm{~h} 33 \\
\text { No data }\end{array}$ & $\begin{array}{l}11 \mathrm{~h} 45 \\
14 \mathrm{~h} 33 \\
16 \mathrm{~h} 38\end{array}$ & $\begin{array}{l}\text { No event } \\
16 h 03 \\
19 h 18\end{array}$ \\
\hline $\begin{array}{l}\text { Max particle flux } \\
(\mathrm{g} \mathrm{m}-2 \mathrm{~d}-1)\end{array}$ & $\begin{array}{l}\text { VE } \\
\text { VV } \\
\text { VA }\end{array}$ & $\begin{array}{l}\text { No data } \\
121 \\
28\end{array}$ & $\begin{array}{l}\text { No data } \\
98 \\
217 \\
\end{array}$ & $\begin{array}{l}\text { Na data } \\
116 \\
137\end{array}$ \\
\hline
\end{tabular}


Table 2 - Characteristic values for each event: 15 December (15D), head (15D-h) and body (15D-b), 5 February (5F), 8 February (8F) and 18 February (18F). Values correspond to maximum integral velocity (Umax) in $\mathrm{m} / \mathrm{s}$, maximum integral thickness (Hmax) in $m$, length $(L)$ in $m$, length per thickness ratio $(L / H)$, maximum sediment concentration (Cmax) in $\mathrm{g}^{-1}$, maximum induced shear stress $\left(\mathrm{T}_{\mathrm{b}}\right)$ in $\mathrm{Pa}$, critical grain size for movement $\left(D_{c}\right)$ in $\mathrm{mm}$, maximum settling flux $(\mathrm{Fs}, \max )$ in $\mathrm{g} \mathrm{m}^{-2} \mathrm{~d}^{-1}$, and mean flux over 7 days $(\mathrm{Fs} / 7)$ in $\mathrm{g} \mathrm{m}^{-2} \mathrm{~d}^{-1}$.

\begin{tabular}{llllllllll}
\hline Event & Umax & Hmax & $\mathrm{L}$ & $\begin{array}{c}100 \\
\mathrm{~L} / \mathrm{H}\end{array}$ & Cmax & $\mathrm{T}_{\mathrm{b}}$ & $\begin{array}{l}\mathrm{Dc} \\
(\mathrm{mm})\end{array}$ & $\begin{array}{l}\mathrm{Fs}, \mathrm{max} \\
\text { Fs/7 } \\
\text { days }\end{array}$ \\
\hline 15 D & 0,37 & 150 & 4000 & 3,8 & 0,66 & 14 & 16 & 7080 & 21 \\
15D-h & 0,32 & 150 & 800 & 19 & 0,53 & 10 & 11,6 & 4352 & - \\
15D-b & 0,37 & 131 & 2000 & 6,6 & 0,66 & 14 & 16,2 & 7080 & - \\
$\mathbf{5 F}$ & 0,27 & 103 & 1250 & 8,2 & 0,4 & 7,06 & 8 & 2522 & 8 \\
$\mathbf{8 F}$ & 0,13 & 40 & 2000 & 2 & 0,15 & 1,7 & 2,3 & 245 & 1,08 \\
18F & 0,15 & 97 & 7000 & 1,4 & 1,55 & 20 & 20 & $5.10^{4}$ & 301 \\
\hline
\end{tabular}




\section{Figures}

Figure. 1: Bathymetric map of the Var submarine canyon showing the locations of the studied stations.

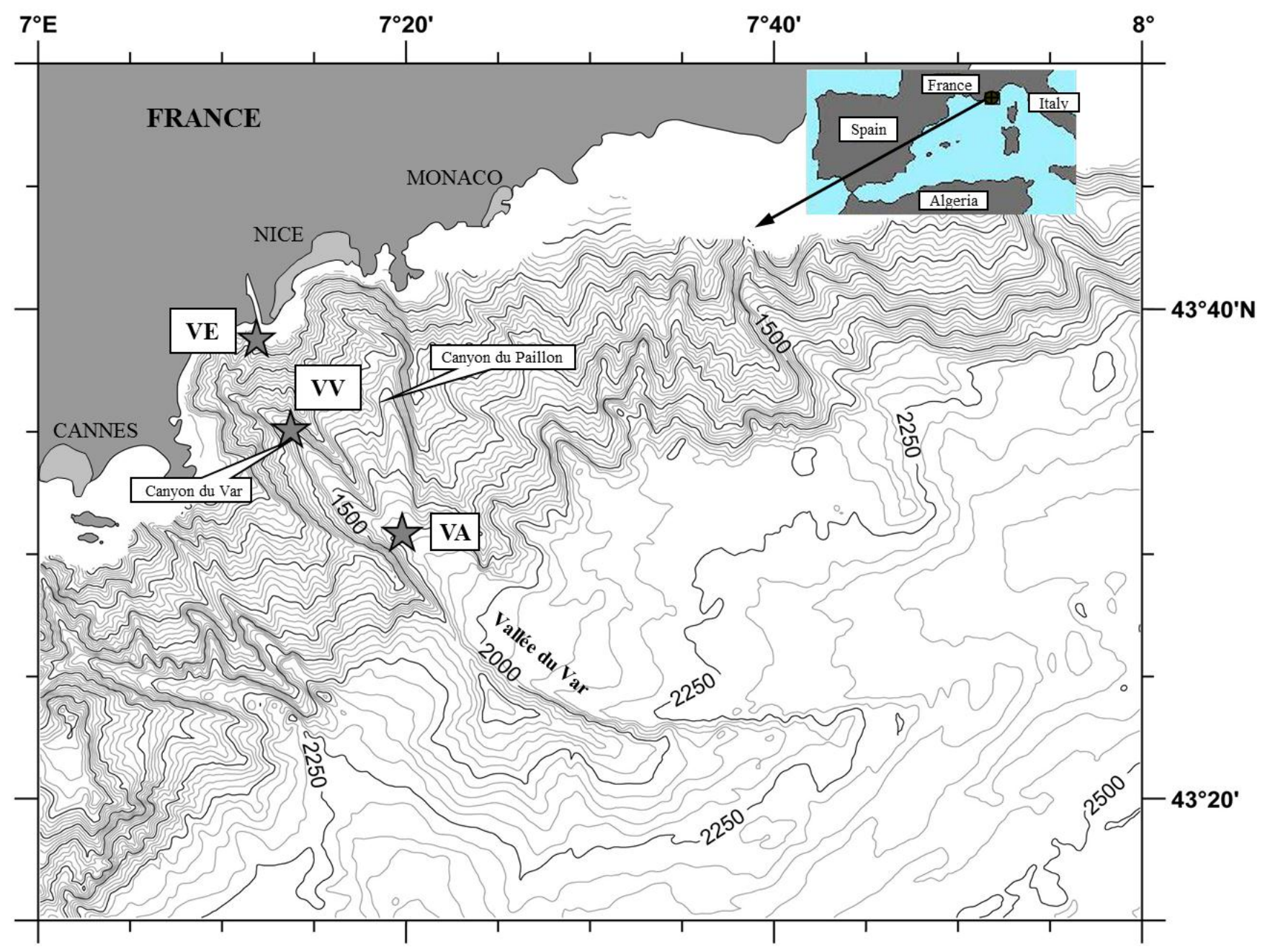


Figure. 2: Hourly measurements of Var River flow, current speed (30 m a.b.) and total particle flux from December 2008 to March 2009 at each station along the Var submarine canyon. The Var River floods are delimited by a pink color and the gravity flows by a blue color.
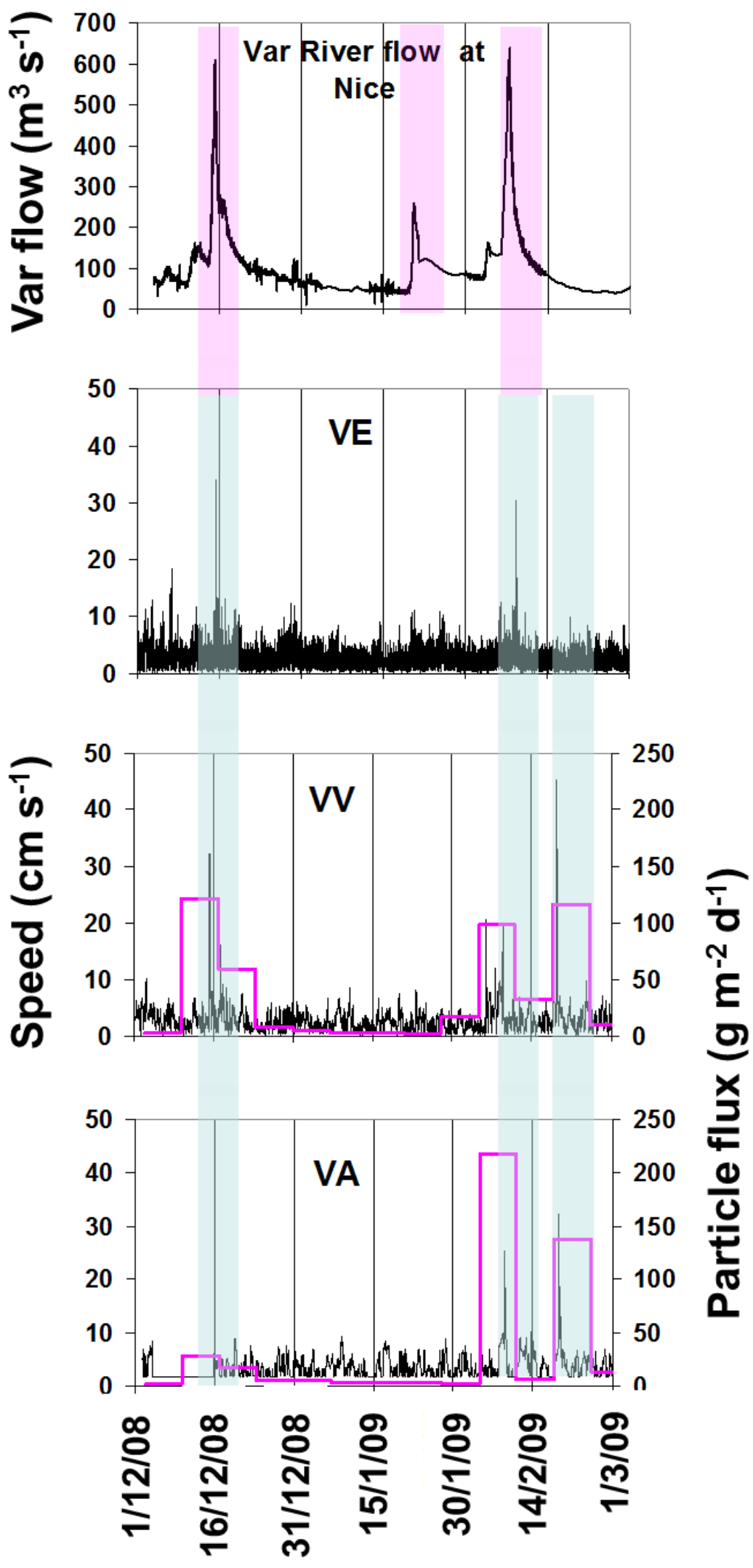
Figure 3: Progressive vector plots created using speed currents measured at $30 \mathrm{~m}$ a.b. from the moorings deployed at the VE, VV and VA stations.
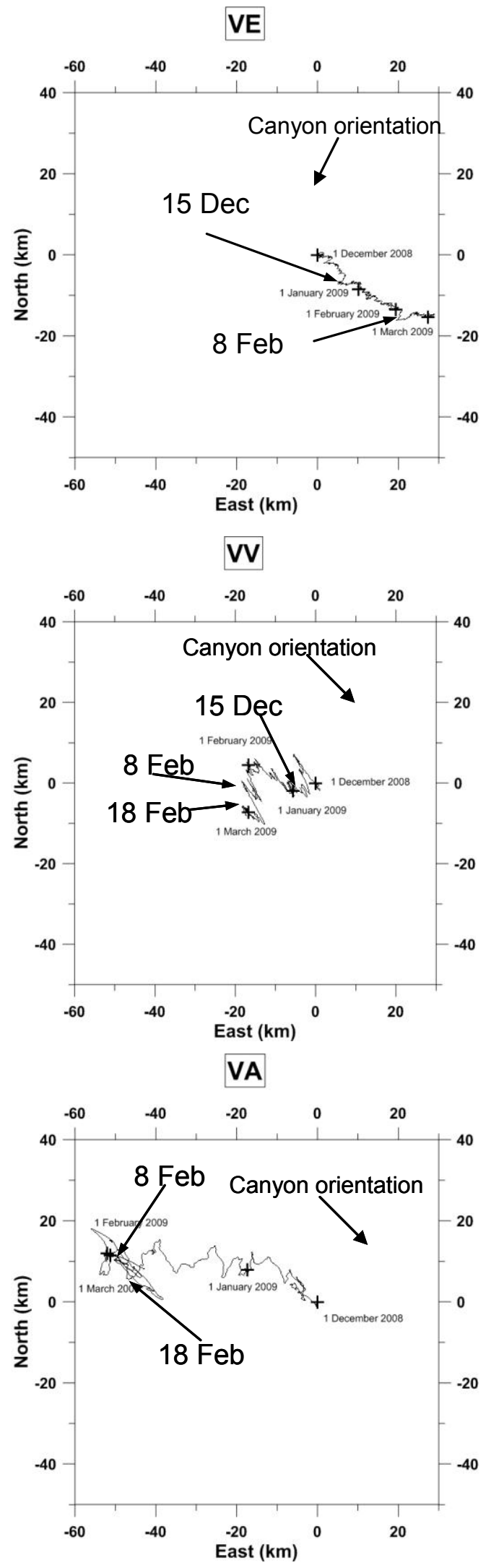
Figure. 4: The 15 December event showing flow, current speed, temperature and turbidity at the VE, VV and VA stations.
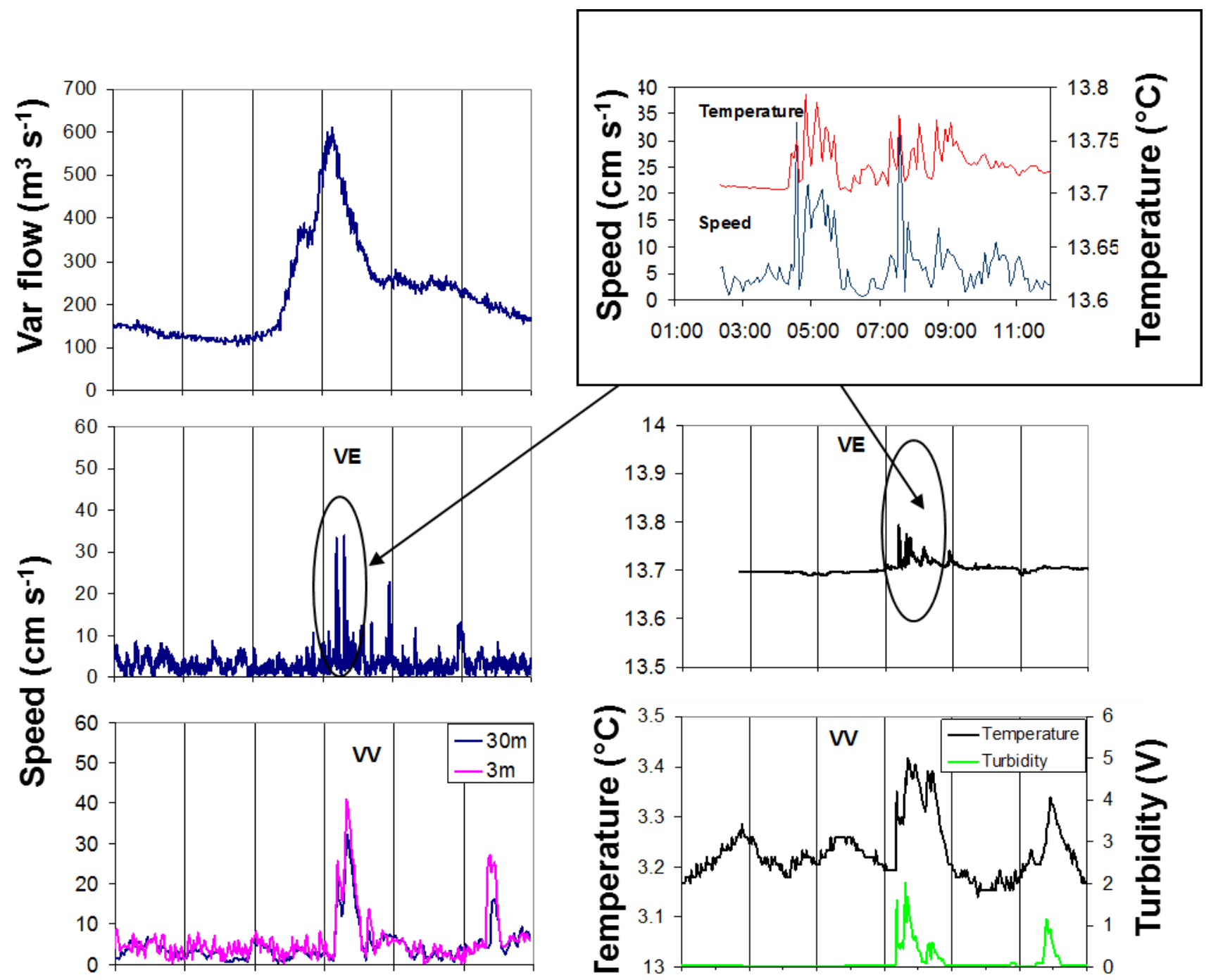

$12 / 12$ 13/12 14/12 15/12 16/12 17/12 18/12
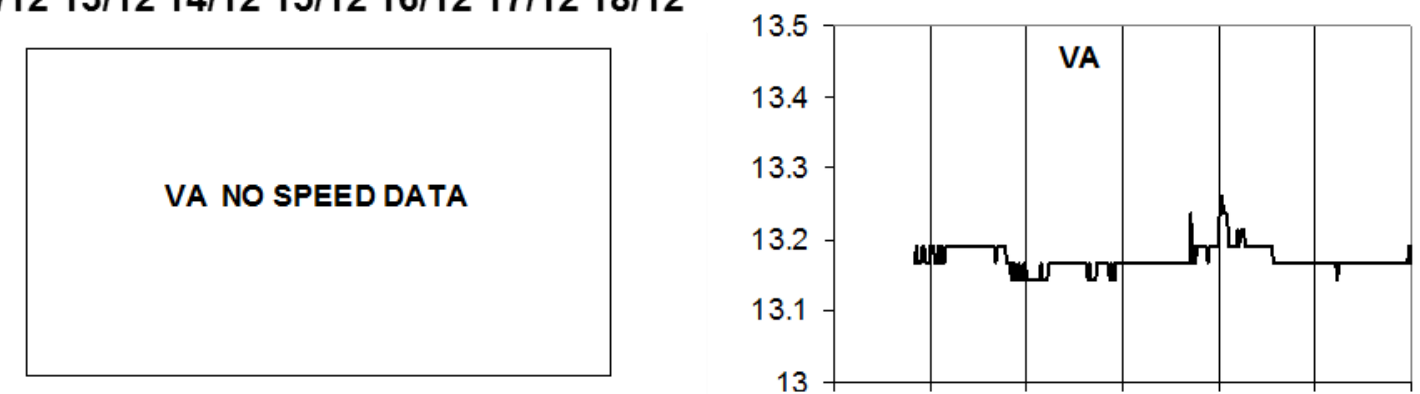

$12 / 1213 / 1214 / 1215 / 1216 / 1217 / 1218 / 12$ 
Figure. 5: Station VV: Horizontal and vertical current measured with the $300 \mathrm{kHz}$ ADCP from 3 to $30 \mathrm{~m}$ altitude, temperature and turbidity at $15 \mathrm{~m}$ above the bottom during the December and February events.
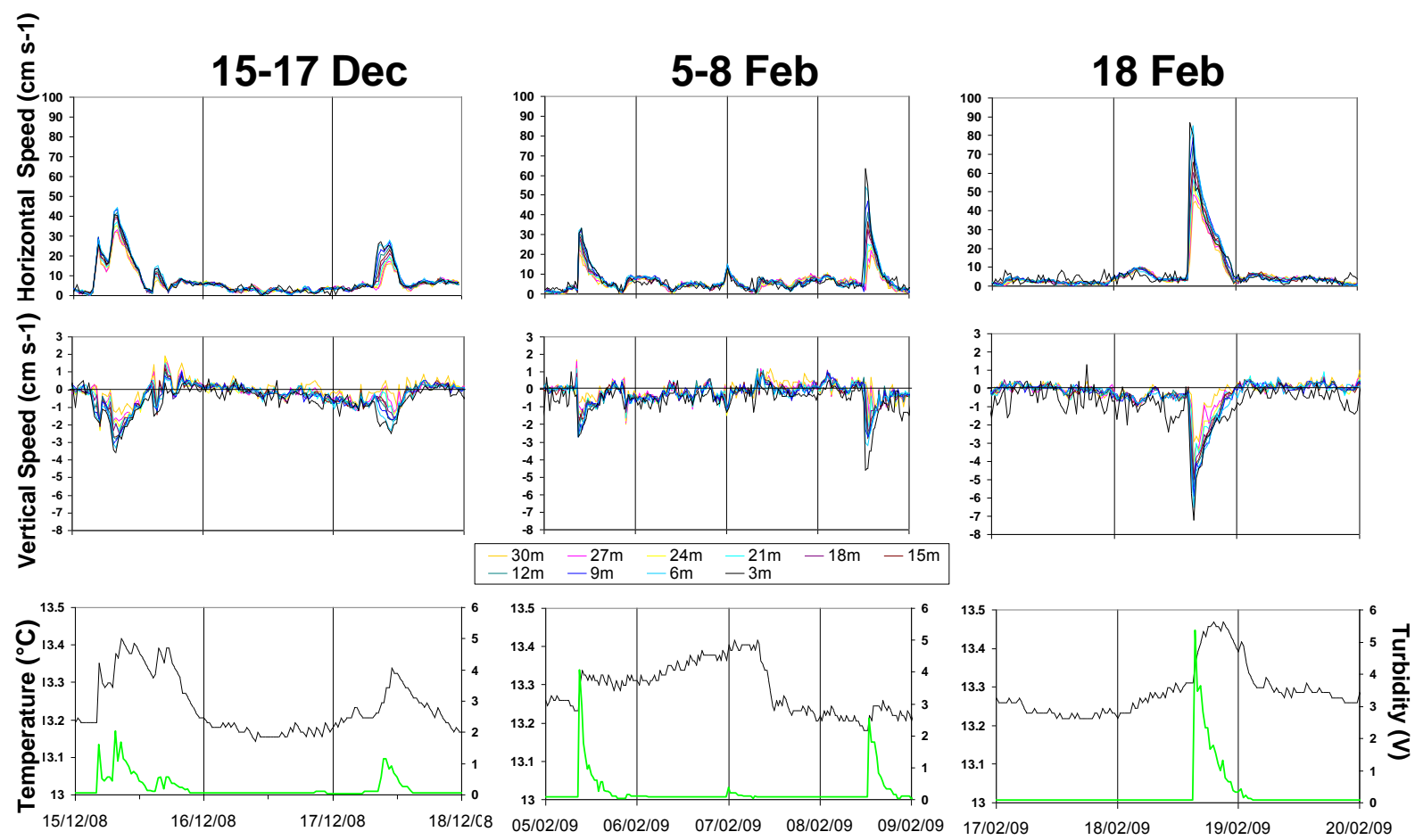
Figure. 6: Total particle fluxes, organic carbon and inorganic carbon concentration of particles sampled at the VV and VA stations.
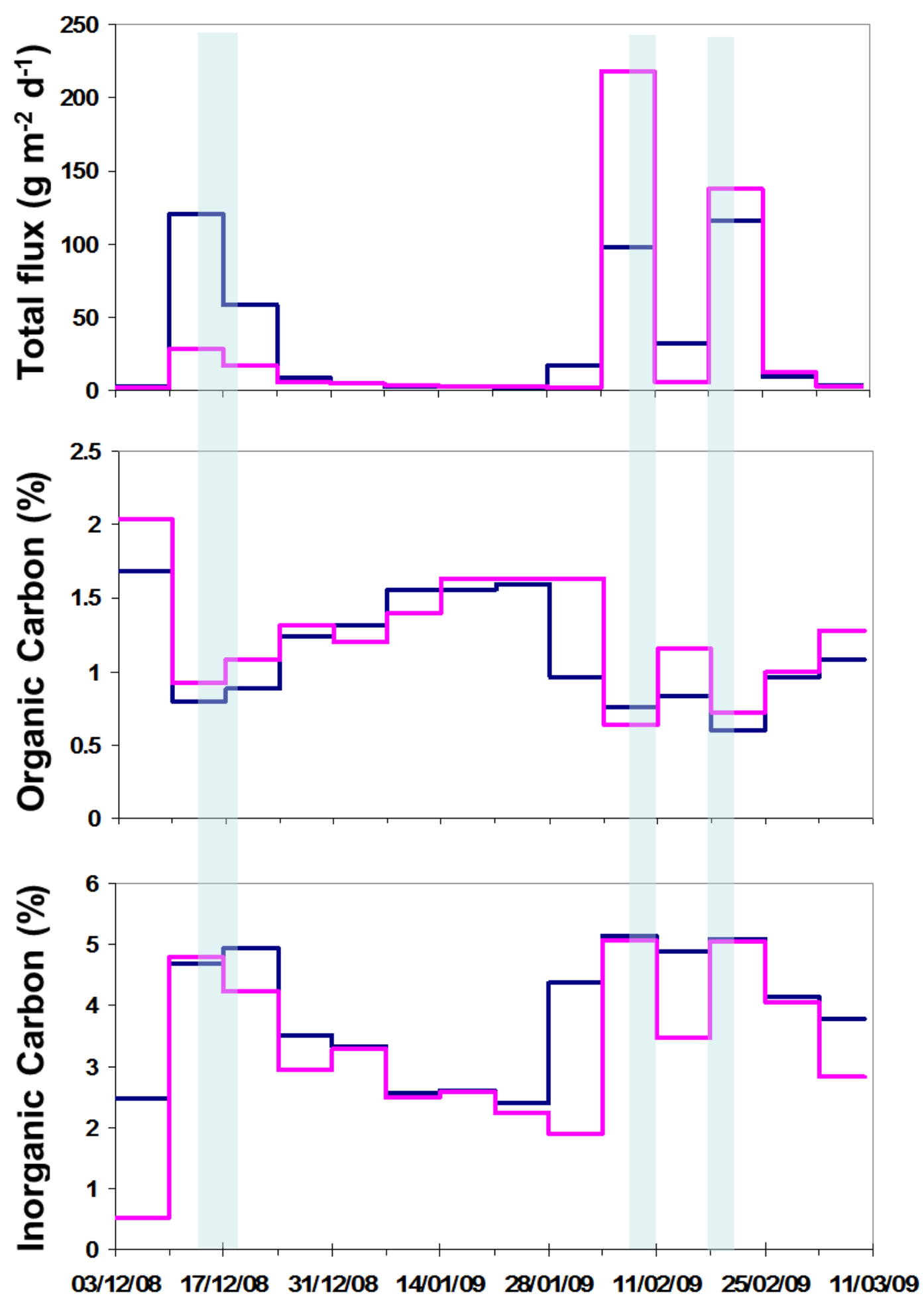

$$
-\mathrm{W}-\mathrm{VA}
$$


Figure. 7: The 8 February event showing the Var River flow, current speed, temperature and turbidity at the VE, VV and VA stations.
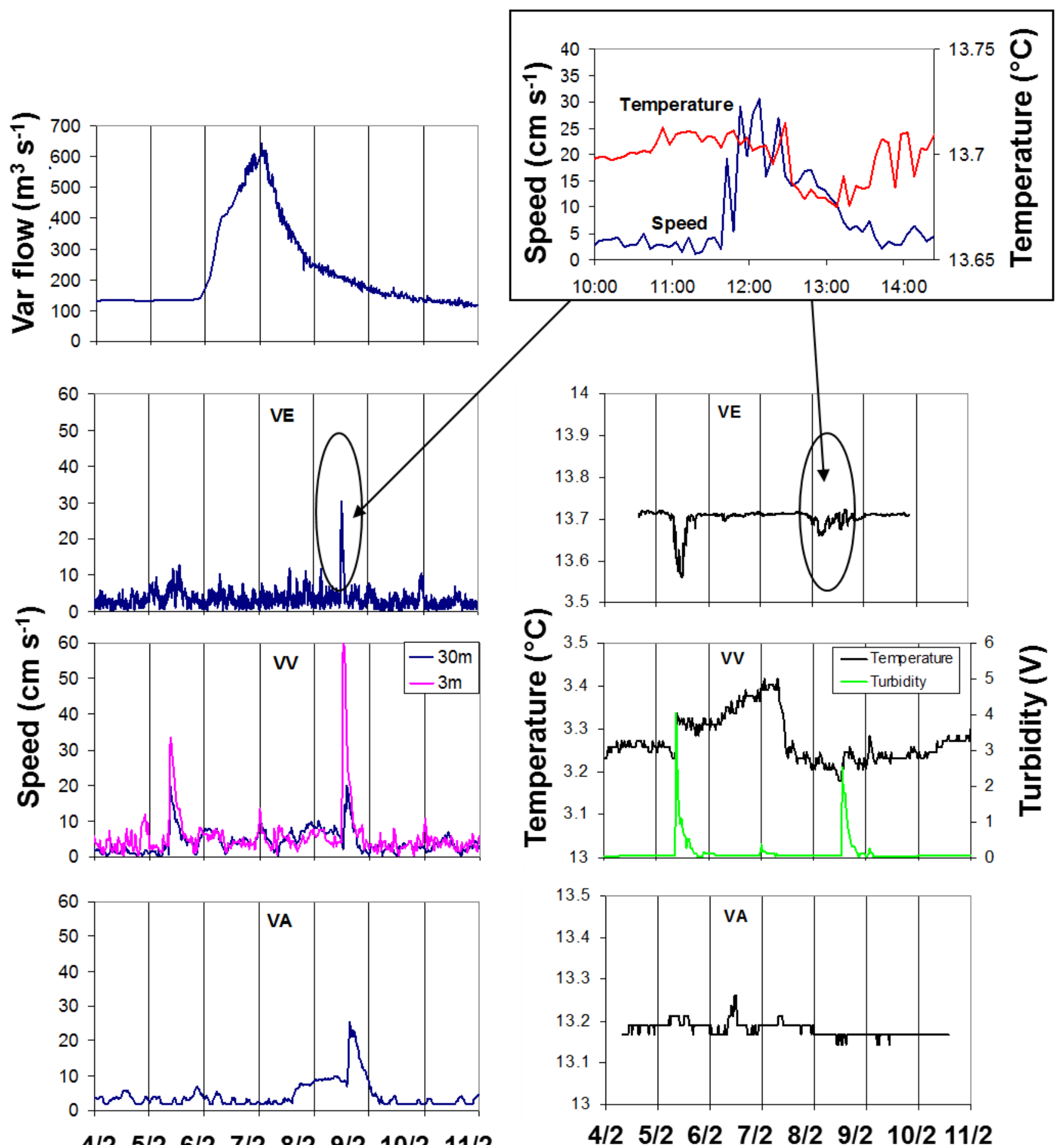

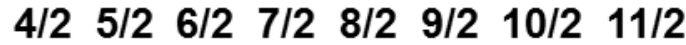


Figure. 8: The 18 February event showing the Var River flow, current speed, temperature and turbidity at the VE, VV and VA stations.
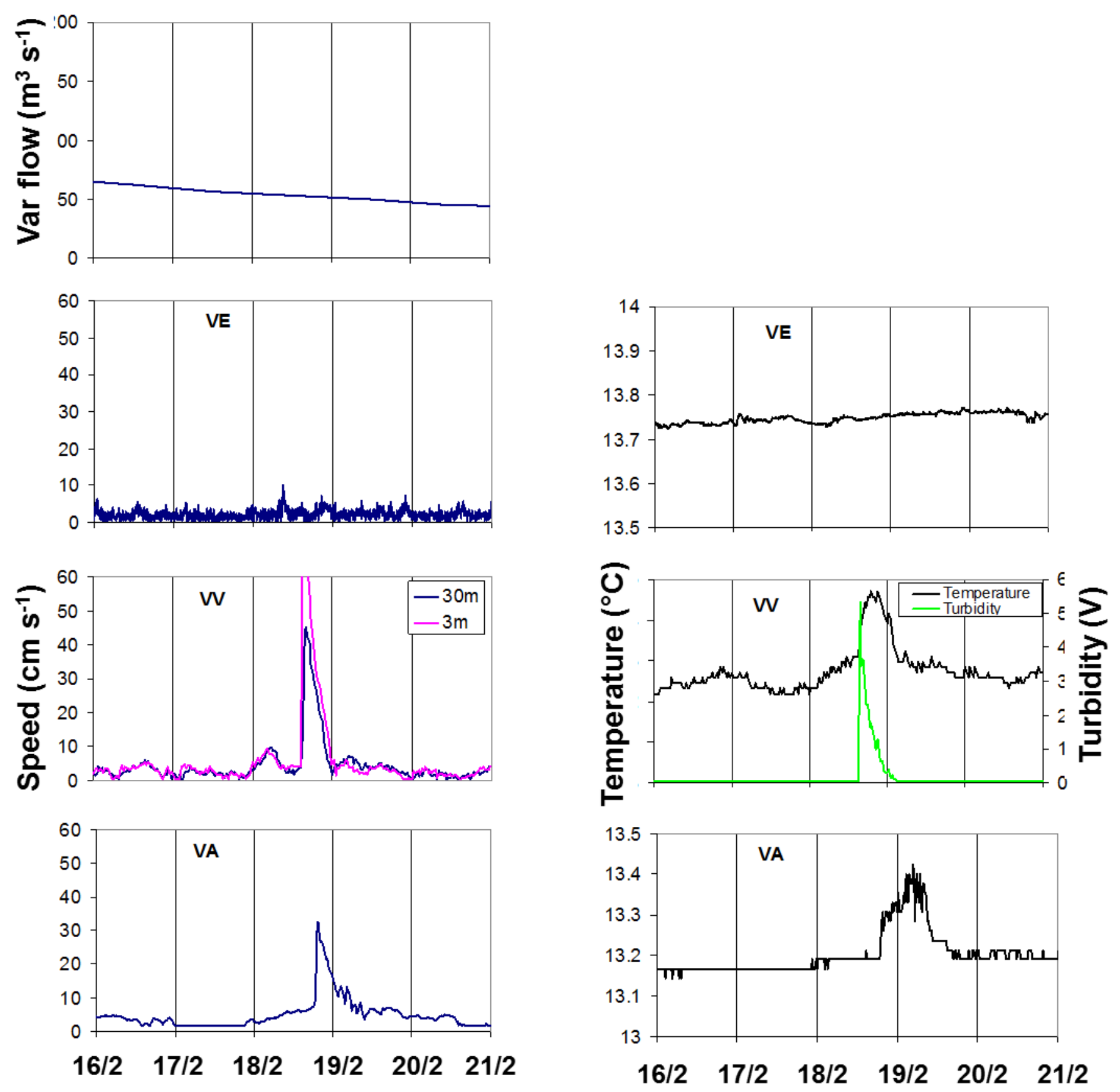
Figure. 9: Horizontal and vertical extension of the turbidity events based on an Eulerian transformation of data at station VV. Colours represent horizontal velocity.
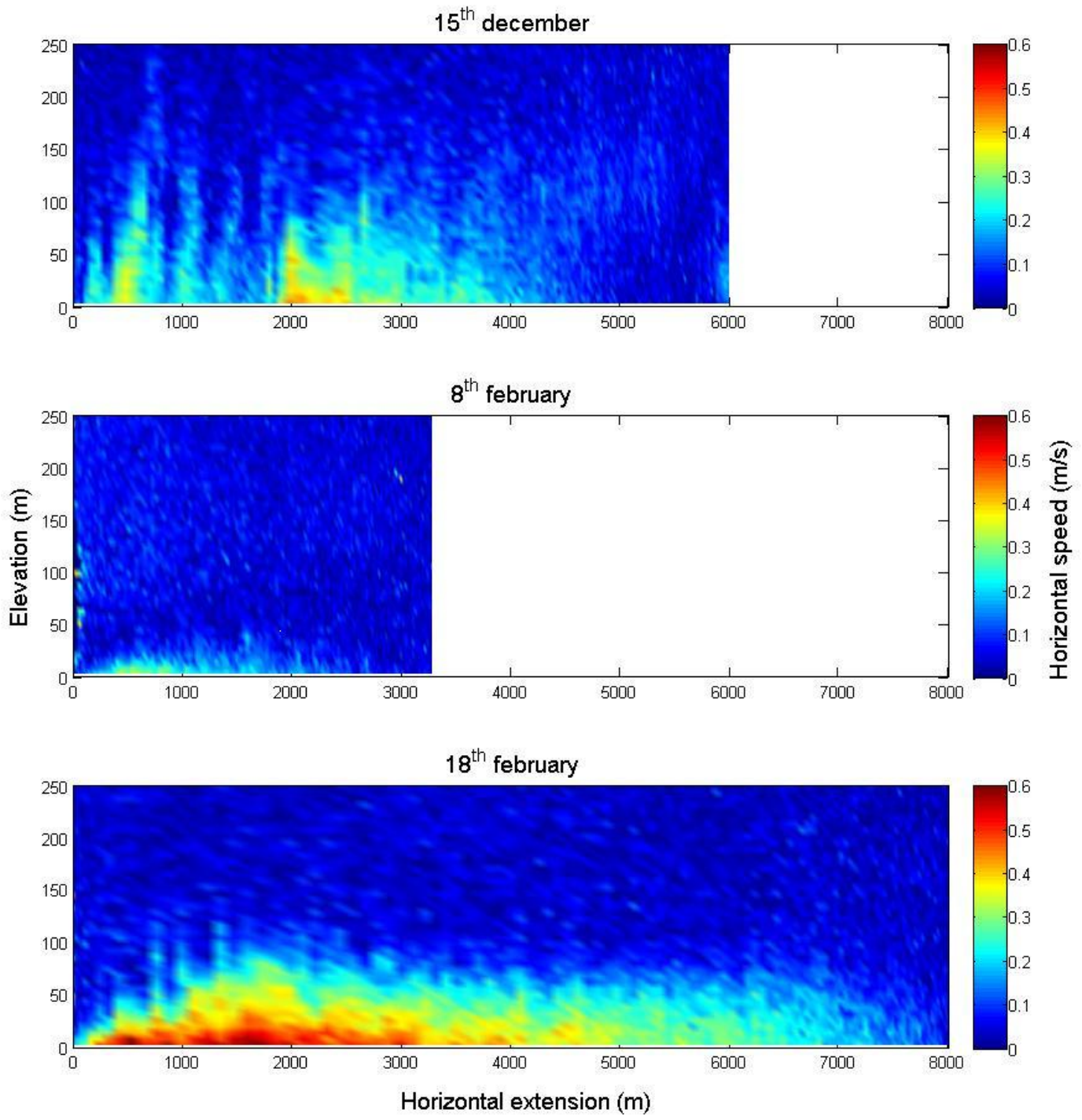
Figure. 10: 3D representations of current velocity as measured with the $75 \mathrm{kHz}$ and $300 \mathrm{kHz}$ ADCP during the December and February events (dashed lines on the $75 \mathrm{kHz}$ ADCP graph represent the upper limits of the $300 \mathrm{kHz}$ ADCP at $30 \mathrm{~m}$ a.b.)
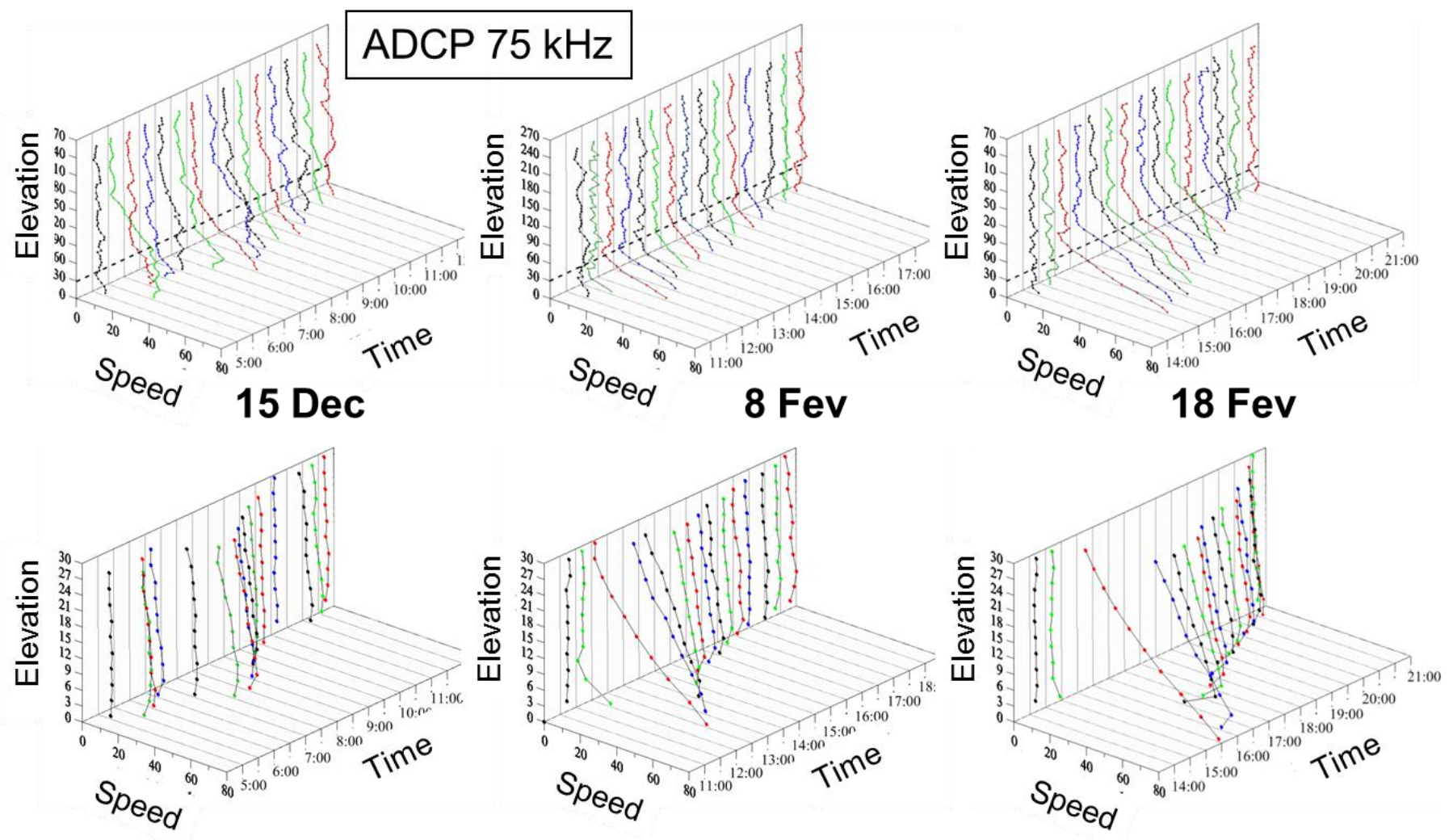

ADCP $300 \mathrm{kHz}$ 
Figure. 11: Time evolution of the estimated sediment concentration and settling flux for the turbidity events. Sediment concentration is estimated supposing a steady balance between slope forcing and square friction (blue line) and using the front-head equation (red dotted line). Settling fluxes (green line) is estimated on the basis of Thorn (1981) settling velocity model.
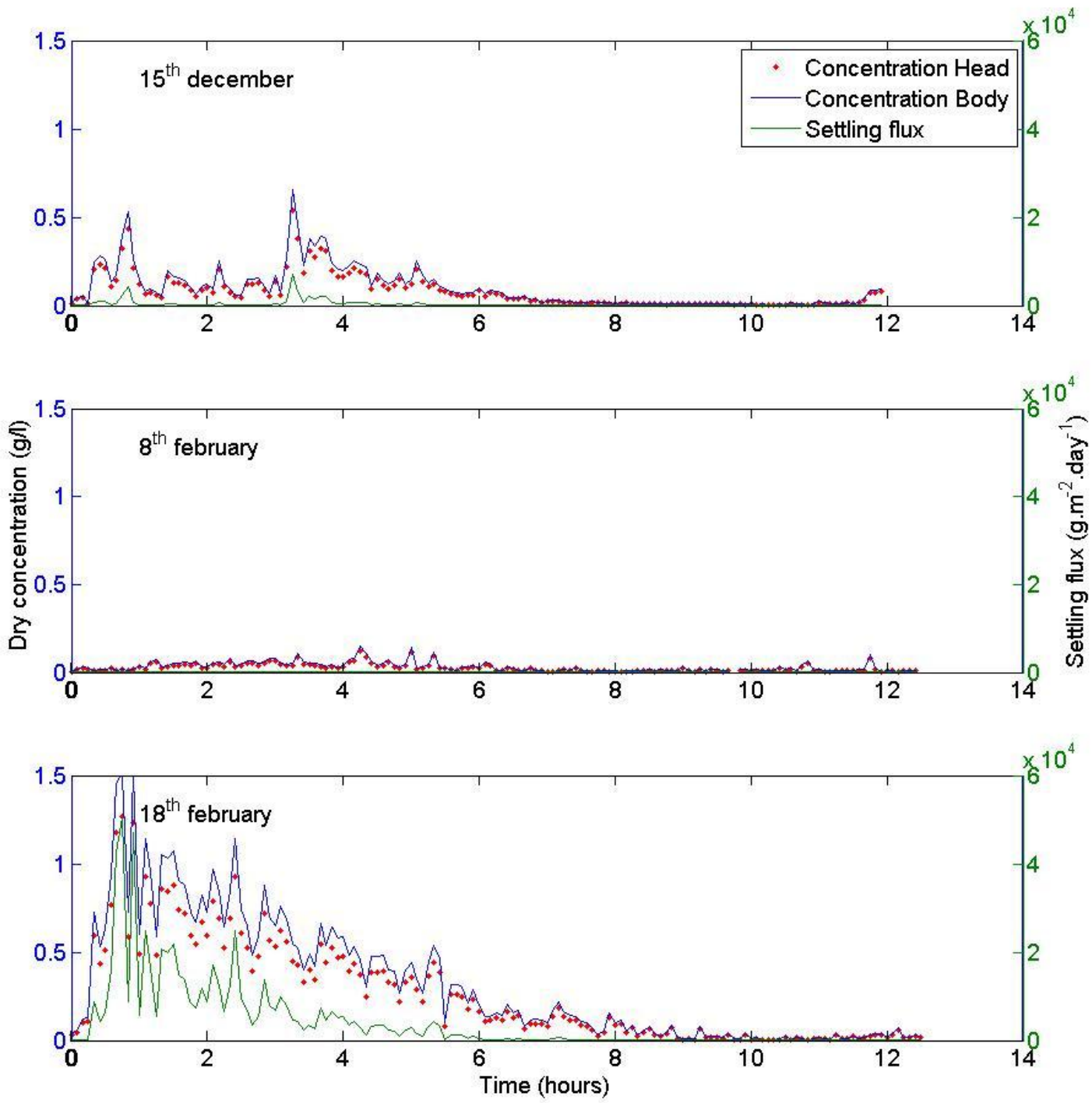
Figure 12: Turbulent mixing based on square friction law (blue line) at the bottom of the flows and integral velocity (red line). Turbulent mixing indicates bottom shear stresses and hence determines the estimated maximum grain size for remobilized sediments.
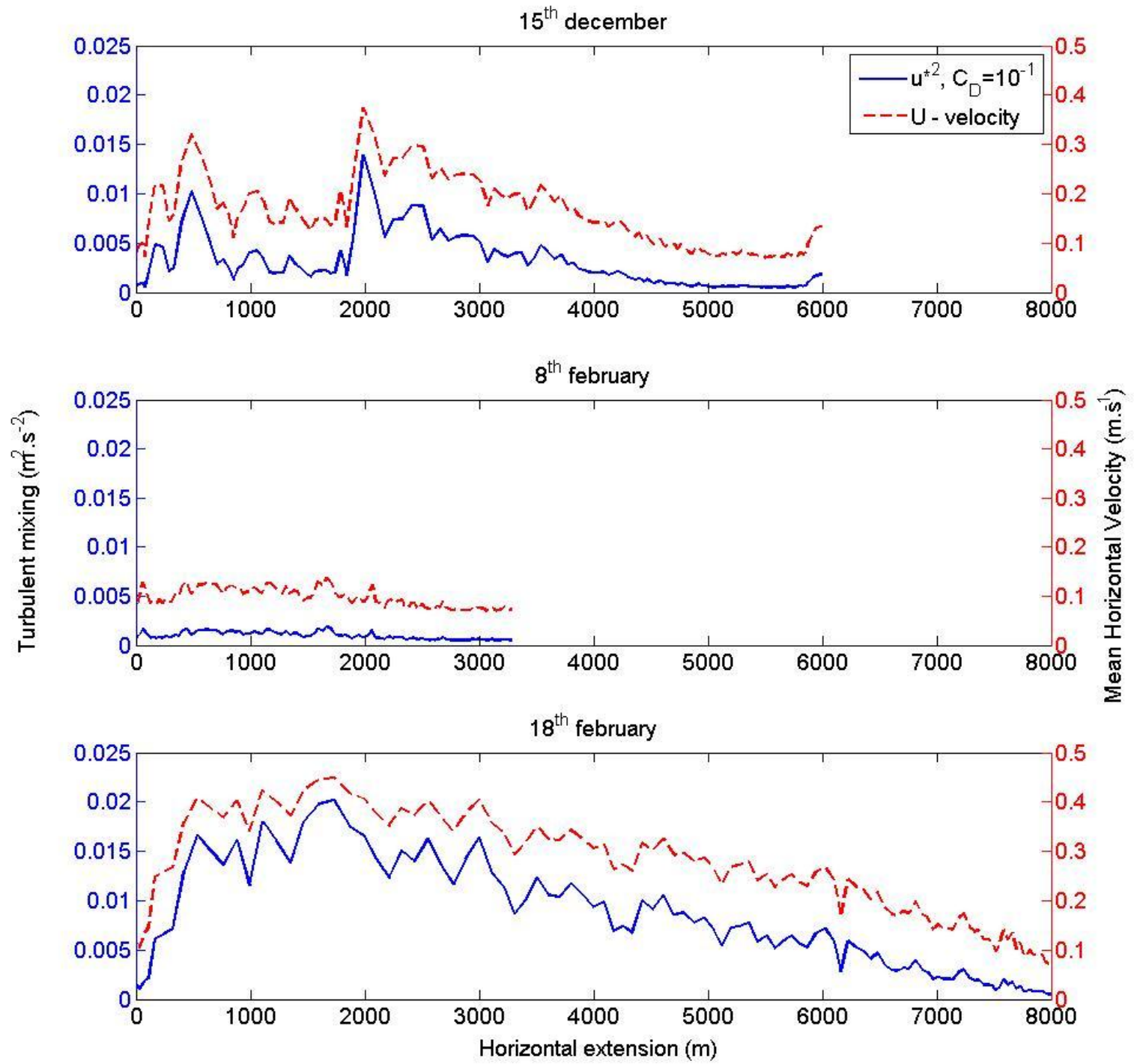